\title{
Article \\ Optimization of the Obtaining of Cellulose Nanocrystals from Agave tequilana Weber Var. Azul Bagasse by Acid Hydrolysis
}

\author{
Manuel Alberto Gallardo-Sánchez ${ }^{1}{ }^{\mathbb{D}}$, Tania Diaz-Vidal ${ }^{2}$, Alejandra Berenice Navarro-Hermosillo ${ }^{1}$, \\ Edgar Benjamin Figueroa-Ochoa $\left.{ }^{3}{ }^{(}\right)$, Rogelio Ramirez Casillas ${ }^{4}$, José Anzaldo Hernández ${ }^{4}$, \\ Luis Carlos Rosales-Rivera ${ }^{2}{ }^{\mathbb{D}}$, J. Felix Armando Soltero Martínez ${ }^{2} \mathbb{B}^{\mathbb{B}}$, Salvador García Enríquez ${ }^{4}$ \\ and Emma Rebeca Macías-Balleza ${ }^{2, *(1)}$
}

Citation: Gallardo-Sánchez, M.A.; Diaz-Vidal, T.; Navarro-Hermosillo, A.B.; Figueroa-Ochoa, E.B.; Ramirez Casillas, R.; Anzaldo Hernández, J.; Rosales-Rivera, L.C.; Soltero

Martínez, J.F.A.; García Enríquez, S.; Macías-Balleza, E.R. Optimization of the Obtaining of Cellulose Nanocrystals from Agave tequilana Weber Var. Azul Bagasse by Acid Hydrolysis. Nanomaterials 2021, 11, 520. https://doi.org/10.3390/ nano11020520

Received: 26 January 2021 Accepted: 12 February 2021 Published: 18 February 2021

Publisher's Note: MDPI stays neutral with regard to jurisdictional claims in published maps and institutional affiliations.

Copyright: (c) 2021 by the authors. Licensee MDPI, Basel, Switzerland. This article is an open access article distributed under the terms and conditions of the Creative Commons Attribution (CC BY) license (https:/ / creativecommons.org/licenses/by/ $4.0 /)$.
1 Departamento de Ingeniería de Proyectos, Centro Universitario de Ciencias Exactas e Ingenierías, Universidad de Guadalajara, Guadalajara C.P. 44430, Mexico; manuel.gallardo@academicos.udg.mx (M.A.G.-S.); alenicenavarro@gmail.com (A.B.N.-H.)

2 Departamento de Ingeniería Química, Centro Universitario de Ciencias Exactas e Ingenierías, Universidad de Guadalajara, Guadalajara C.P. 44430, Mexico; taniadzv@gmail.com (T.D.-V.); carlos.rosales@academicos.udg.mx (L.C.R.-R.); jfasm@hotmail.com (J.F.A.S.M.)

3 Departamento de Química, Centro Universitario de Ciencias Exactas e Ingenierías, Universidad de Guadalajara, Guadalajara C.P. 44430, Mexico; benjamin.figueroa@academicos.udg.mx

4 Departamento de Madera Celulosa y Papel, Centro Universitario de Ciencias Exactas e Ingenierías, Universidad de Guadalajara, Zapopan C.P. 45020, Mexico; roramire@gmail.com (R.R.C.); j.anzaldo@academicos.udg.mx (J.A.H.); salgaren@hotmail.com (S.G.E.)

* Correspondence: emma.macias@academicos.udg.mx; Tel.: +52-33-13-78-59-00 (ext. 27591)

Abstract: A multilevel factorial design of $2^{3}$ with 12 experiments was developed for the preparation of cellulose nanocrystals (CNC) from Agave tequilana Weber var. Azul bagasse, an agro-industrial waste from tequila production. The studied parameters were acid type $\left(\mathrm{H}_{2} \mathrm{SO}_{4}\right.$ and $\left.\mathrm{HCl}\right)$, acid concentration ( 60 and $65 \mathrm{wt} \%$ for $\mathrm{H}_{2} \mathrm{SO}_{4}, 2$ and $8 \mathrm{~N}$ for $\mathrm{HCl}$ ) temperature ( 40 and $60{ }^{\circ} \mathrm{C}$ for $\mathrm{H}_{2} \mathrm{SO}_{4}$, 50 and $90{ }^{\circ} \mathrm{C}$ for $\mathrm{HCl}$ ), and hydrolysis time (40, 55 and $70 \mathrm{~min}$ for $\mathrm{H}_{2} \mathrm{SO}_{4}$; and 30, 115 and $200 \mathrm{~min}$ for $\mathrm{HCl}$ ). The obtained $\mathrm{CNC}$ were physical and chemically characterized using dynamic light scattering (DLS), atomic force microscopy (AFM), Fourier-transform infrared spectroscopy (FT-IR), $\mathrm{X}$-ray photoelectron spectroscopy (XPS), and X-ray diffraction (XDR) techniques. The maximum CNC yield was 90 and $96 \%$ for $\mathrm{HCL}$ and $\mathrm{H}_{2} \mathrm{SO}_{4}$, respectively, and the crystallinity values ranged from $88-91 \%$. The size and morphology of A. tequilana CNC strongly depends on the acid type and hydrolysis time. The shortest $\mathrm{CNC}$ obtained with $\mathrm{H}_{2} \mathrm{SO}_{4}\left(65 \mathrm{wt} \%, 40{ }^{\circ} \mathrm{C}\right.$, and $\left.70 \mathrm{~min}\right)$ had a length of $137 \pm 68 \mathrm{~nm}$, width $33 \pm 7 \mathrm{~nm}$, and height $9.1 \mathrm{~nm}$, whereas the shortest CNC obtained with $\mathrm{HCl}(2 \mathrm{~N}$, $50{ }^{\circ} \mathrm{C}$ and $30 \mathrm{~min}$ ) had a length of $216 \pm 73 \mathrm{~nm}$, width $69 \pm 17 \mathrm{~nm}$, and height $8.9 \mathrm{~nm}$. In general, the obtained $\mathrm{CNC}$ had an ellipsoidal shape, whereas $\mathrm{CNC}$ prepared from $\mathrm{H}_{2} \mathrm{SO}_{4}$ were shorter and thinner than those obtained with $\mathrm{HCl}$. The total sulfate group content of $\mathrm{CNC}$ obtained with $\mathrm{H}_{2} \mathrm{SO}_{4}$ increased with time, temperature, and acid concentration, exhibiting an exponential behavior of $C_{S G}=a e^{b t}$.

Keywords: Agave tequilana; bagasse; cellulose nanocrystals; acid hydrolysis; AFM; factorial design

\section{Introduction}

Cellulose nanocrystals $(\mathrm{CNC})$ are highly crystalline nanoparticles shaped like an elongated bar, with diameters between $2-20 \mathrm{~nm}$, and lengths of $<500 \mathrm{~nm}[1,2]$. CNC have desirable physical, chemical, and mechanical properties, such as an elastic modulus around $150 \mathrm{GPa}$, which is greater than the elastic modulus of glass fibers (85 GPa) and aramid ( $65 \mathrm{GPa}$ ) [3-5], high tensile strength (7500 MPa), high stiffness (Young's modulus $\geq 140 \mathrm{GPa}$ ), a high surface area, high aspect ratio, an abundance of surface hydroxyl groups available for chemical functionalization, and full biodegradability, due to its natural origin [1-4,6]. Therefore, CNC have been applied in diverse fields such as medicine [2], catalysis [7], 
biosensing [8], and as reinforcing materials to improve the mechanical properties of composites in multiple applications, such as plastics, ceramics, concrete, etc. [9]. Recently, it has been observed that the reinforcement of cementitious materials with cellulose microcrystals $(\mathrm{CMC})$ and $\mathrm{CNC}$ at concentrations $<2 \mathrm{wt}$ \% improve the flexural and compressive strength between 20 and $50 \%$ of the final material [10-12], and the tensile strength and Young's modulus of reinforced poly(3-hydroxybutyrate-co-3-hydroxyvalerate) (PHBV) with $12 \%$ of CNC-H were improved by 175 and $300 \%$, respectively [13].

Typically, CNC are obtained through the removal of the amorphous cellulose regions by chemical means $[3,6]$. The prior purified cellulose material is subjected to hydrolysis with a strong acid under strictly controlled conditions, followed by dialysis in water and successive washes to remove the free acid. Usually, an extra step with ultrasound and filtration is considered to separate residues and ensure a stable colloidal suspension $[5,14,15]$. The amorphous regions in the cellulose chains are more susceptible to acid hydrolysis than crystalline regions, thus the breakdown of glycosidic bonds is facilitated, releasing the individual crystals. $\mathrm{H}_{2} \mathrm{SO}_{4}$ and $\mathrm{HCl}$ are frequently used for the preparation of $\mathrm{CNC}$, however phosphoric and hydrobromic acids have been regularly employed [16]. The most studied parameters for acid extractions with $\mathrm{H}_{2} \mathrm{SO}_{4}$ include hydrolysis time from $40-70 \mathrm{~min}$, temperatures ranging from $40-60^{\circ} \mathrm{C}$ and acid concentrations between $60-65 \mathrm{wt} \%$ [15-21]. In the case of $\mathrm{HCl}$, the most used conditions are $30-200 \mathrm{~min}, 60-110^{\circ} \mathrm{C}$, and concentrations from 2-8 N [13,22-24].

Agave tequilana Weber var. Azul is the main resource in the tequila industry. To generate $1 \mathrm{~L}$ of tequila, $A$. tequilana heads are cooked and crushed to extract the sugars, to finally generate approximately $1.4 \mathrm{~kg}$ of bagasse in wet weight. According to the Tequila Regulatory Council, 523,600 tons of bagasse from all the A. tequilana varieties were obtained in the process of tequila generation solely in 2020, of which 319,620 tons corresponded to A. tequilana Weber var. Azul [25]. The excess bagasse creates an enormous environmental impact in terms of agro-waste management and disposal [26]. Extensive effort has focused on the comprehensive exploitation of $A$. tequilana bagasse in the last decade. Many studies point to the high cellulose content of $A$. tequilana bagasse, close to $80 \%[27,28]$, as the main source for the production of high-added value sub-products, such as cellulose nanocrystals [29].

Depending on the cellulose raw material pretreatment and hydrolysis process, CNC with tunable properties can be obtained [30]. CNC extracted with $\mathrm{HCl}$ show poor colloidal stability, whereas $\mathrm{CNC}$ produced with $\mathrm{H}_{2} \mathrm{SO}_{4}$ form highly stable colloidal dispersions due to electrostatic repulsion caused by negatively charged sulfate ester groups on their surface [31]. Increasing temperatures and reaction times have been associated with smaller nanocrystal sizes; however, severe reaction conditions can reduce the yield and shorten the crystal size [19,32]. Thus, a comprehensive study analyzing acid concentration and determining the best operational output is mandatory to universally optimize the obtaining of CNC. In this sense, the design of a factorial experiment can be employed to optimize the process of $\mathrm{CNC}$ production from $A$. tequilana bagasse. The design aims to determine if the principal factors are statistically significant based on a null hypothesis test, with a confidence value of $p<0.05$ [22,33]. Compared to one-factor-at-a-time experiments, factorial designs allow the detection and study of interactions in a more efficient way [34]. This technique has already been employed to optimize the isolation and production of microcrystalline and nanocrystalline cellulose from recycled wood pulp [35], Picea abies [36], and Acacia farnesiana L. Willd bagasse [37] with a reduced number of experiments, time, and cost.

In the present work, two multilevel factorial $2^{3}$ experimental designs were selected to optimize the process of CNC isolation from $A$. tequilana by acid hydrolysis with $\mathrm{H}_{2} \mathrm{SO}_{4}$ and $\mathrm{HCl}$. The studied factors were acid concentration, reaction time, and temperature. To determine the best and statistically significant operational conditions, the CNC dimensions of length $(\mathrm{L})$, height $(\mathrm{H})$, and width $(\mathrm{W})$ were measured from AFM images, while diameter (d) of dispersed particles were measured from DLS. The reaction yields of all studied 
parameters were also compared. Finally, the obtained $\mathrm{CNC}$ were chemically characterized with XPS, FTIR, and XRD.

\section{Materials and Methods}

\subsection{Materials}

Bagasse from A. tequilana Weber var. Azul was kindly donated by Mundo Agave (Tequila, Jalisco, Mexico). Sulfuric acid $\left(\mathrm{H}_{2} \mathrm{SO}_{4}, 97 \mathrm{wt} \%\right)$ and hydrochloric acid $(\mathrm{HCl}$, $37 \mathrm{wt} \%$ ) were obtained from Golden Bell (Mexico). Dialysis membranes Spectra/Por 4 MWCO 12-14 KDa were purchased from Thomas-Scientific (Swedesboro, NJ, USA). Filters were provided by Thermo Fisher Scientific (Waltham, MA, USA). All solutions were prepared using milli-Q water with a resistivity of $18.2 \mathrm{MOhm} \times \mathrm{cm}$ at $25^{\circ} \mathrm{C}$.

\subsection{Experimental Design}

Two multilevel factorial designs of $2^{3}$ were developed via STATGRAPHICS Centurion XVI (The Plains, VA, USA) to investigate the effect of acid concentration, hydrolysis time, and temperature on the final length measured using DLS and AFM, and yield of CNC produced from A. tequilana Weber var. azul. The experimental factor details are described in Table 1 and the detailed list of controllable process factors is shown in Table 2. CNC obtained by $\mathrm{H}_{2} \mathrm{SO}_{4}$ and HCL hydrolysis will be denoted as CNC-S and $\mathrm{CNC}-\mathrm{H}$, respectively.

Table 1. Controllable process factors and their respective levels for CNC acid hydrolysis length optimization.

\begin{tabular}{ccccccc}
\hline & \multicolumn{3}{c}{$\mathbf{H}_{\mathbf{2}} \mathbf{S O}_{\mathbf{4}}$} & $\mathbf{H C l}$ \\
\hline & $-\mathbf{1}$ & $\mathbf{0}$ & $\mathbf{+ 1}$ & $-\mathbf{1}$ & $\mathbf{0}$ & $\mathbf{+ 1}$ \\
\hline Concentration & $60 \mathrm{wt} \%$ & - & $65 \mathrm{wt} \%$ & $2 \mathrm{~N}$ & - & $8 \mathrm{~N}$ \\
Temperature $\left({ }^{\circ} \mathrm{C}\right)$ & 40 & - & 60 & 50 & - & 90 \\
Time (min) & 40 & 55 & 70 & 30 & 115 & 200 \\
\hline
\end{tabular}

Table 2. Multilevel factorial design $2^{3}$ process factors for CNC acid hydrolysis length optimization.

\begin{tabular}{cccccccc}
\hline \multicolumn{2}{c}{$\mathbf{H}_{\mathbf{2}} \mathbf{S O}_{\mathbf{4}}$} & & & \multicolumn{3}{c}{$\mathbf{H C l}$} \\
\hline Sample & $\begin{array}{c}\text { Conc. } \\
(\mathbf{w t} \%)\end{array}$ & $\begin{array}{c}\mathbf{T} \\
\left({ }^{\circ} \mathbf{C}\right)\end{array}$ & $\begin{array}{c}\mathbf{t} \\
(\mathbf{m i n})\end{array}$ & Sample & $\begin{array}{c}\text { Conc. } \\
\mathbf{( N )}\end{array}$ & $\begin{array}{c}\mathbf{T} \\
\left({ }^{\circ} \mathbf{C}\right)\end{array}$ & $\begin{array}{c}\mathbf{t} \\
(\mathbf{m i n})\end{array}$ \\
\hline E1S & 60 & 40 & 40 & E1H & 2 & 50 & 30 \\
E2S & 65 & 40 & 40 & E2H & 8 & 50 & 30 \\
E3S & 60 & 60 & 40 & E3H & 2 & 50 & 200 \\
E4S & 65 & 60 & 40 & E4H & 8 & 50 & 200 \\
E5S & 60 & 40 & 70 & E5H & 2 & 90 & 30 \\
E6S & 65 & 40 & 70 & E6H & 8 & 90 & 30 \\
E7S & 60 & 60 & 70 & E7H & 2 & 90 & 200 \\
E8S & 65 & 60 & 70 & E8H & 8 & 90 & 200 \\
E9S & 60 & 40 & 55 & E9H & 2 & 50 & 115 \\
E10S & 65 & 40 & 55 & E10H & 8 & 50 & 115 \\
E11S & 60 & 60 & 55 & E11H & 2 & 90 & 115 \\
E12S & 65 & 60 & 55 & E12H & 8 & 90 & 115 \\
\hline
\end{tabular}

\subsection{Preparation of Cellulose Nanocrystals}

Soluble-grade cellulose pulp from A. tequilana was obtained according to GallardoSánchez et al. [27]. Briefly, soluble-grade cellulose was ground with an IKA MF 10 mill (Staufen, Germany) until particles passing through the $0.5 \mathrm{~mm}$ sieve were obtained. The hydrolysis was carried out with variable conditions of concentration, temperature, and 
time (Table 2), with 12 different conditions for each acid. The acidic solutions were prepared and poured into a three-necked reactor with a capacity of $1 \mathrm{~L}$, and then the solution was heated in an isothermal Haake bath C1 (Vreden, Germany), with a mechanical stirrer RZR 50 Caframo (Ontario, Canada) at $300 \mathrm{rpm}$. Next, $20 \mathrm{~g}$ of soluble-grade cellulose (dry base) were added at the corresponding time. Ratios of 10:1 $(v / w)$ and 30:1 $(v / w)$ were used for the hydrolysis with $\mathrm{H}_{2} \mathrm{SO}_{4}$ and $\mathrm{HCl}$, respectively.

After the hydrolysis reaction, the CNC solution was poured into deionized water at $4{ }^{\circ} \mathrm{C}$, centrifuged (4696 rcf, for $45 \mathrm{~min}$ ), and the precipitates were dialyzed in deionized water $(12-14 \mathrm{KDa})$ at room temperature until the $\mathrm{pH}$ reached a value of 5.5. The water was replaced every $12 \mathrm{~h}$. Afterwards, the CNC were sonicated for $8 \mathrm{~min}$ in an Elma ultrasound bath model TI-H-15 (Singen, Germany), filtered through 2, 1.5, and $1 \mu \mathrm{m}$ filters, and stored at $4{ }^{\circ} \mathrm{C}$ until further use.

\subsection{Determination of Sulfate Groups in CNC-S}

The residual concentration of sulfate groups on the CNC-S surface $(\mathrm{mmol} / \mathrm{kg})$ was measured by conductometric titration, as reported for CNC from huizache wood [32]. A Thermo Fisher Scientific Orion Star A211 potentiometer (Waltham, MA, USA) was used. The titration of sulfate groups $\left(C_{S G}\right)$ was performed using $0.05 \mathrm{~N} \mathrm{NaOH}$ and $30 \mathrm{~mL}$ of a CNC-S solution in $150 \mathrm{~mL}$ of deionized water in a three-neck flask. The analysis of the samples started by adding $0.5-1 \mathrm{~mL}$ of $\mathrm{NaOH}$ to the $\mathrm{CNC}$ suspension at a constant stirring. $\mathrm{pH}$ and conductivity values were recorded until no further variations were detected. $V_{2}$ was determined from the intercept of two slopes obtained from the conductivity vs $\mathrm{NaOH}$ volume plot. The sulfate groups were calculated as follows:

$$
C_{S G}=C t * \frac{V_{2}}{m}
$$

where $C_{S G}$ is the total sulfate groups content in $\mathrm{mmol} / \mathrm{kg}, C t$ is the $\mathrm{NaOH}$ concentration (in this case, $0.05 \mathrm{~N}$ ), $V_{2}$ is the $\mathrm{NaOH}$ consumed volume in $\mathrm{mL}$, and $m$ is the dried mass of CNC-S in $g$.

\subsection{X-ray Photoelectron Spectroscopy (XPS)}

XPS, which is a quantitative analysis method, measures the energy of excited electrons with an X-ray beam, at the lowest energy levels. This technique is performed within the first $10 \mathrm{~nm}$ of the surface and allows to identify the elemental composition at atomic concentrations greater than $0.1 \%$ (except for $\mathrm{H}$ and $\mathrm{He}$ ), with an error <10\% [38]. Monochromatic radiation $(\mathrm{Al} k \alpha$ radiation, $\mathrm{h} v=1486.7 \mathrm{eV}$ ) for XPS was generated using a SPECS $\mathrm{GmbH}$ XR50M twin anode X-ray source and a Phoibos 150 spectrometer with one-dimensional detector 1D-DLD (Berlin, Germany). XPS spectra were taken at an electro emission angle of $90^{\circ}$. The calibration of binding energy was realized with $\mathrm{C} 1 \mathrm{~s}$ peak at $284.8 \mathrm{eV}$. The XPS survey and high resolution spectra of soluble grade cellulose pulp and CNC were recorded. The analyses were carried out with a pass energy of $30 \mathrm{eV}$ and 2 scans for survey, and $15 \mathrm{eV}$ and 20 scans for high resolutions spectra. The elements $\mathrm{O}, \mathrm{S}$, and $\mathrm{C}$ were analyzed using the lines $\mathrm{C} 1 \mathrm{~s}, \mathrm{O} 1 \mathrm{~s}$, and $\mathrm{S} 2 \mathrm{p}$. Once the high resolution spectra were acquired, the component deconvolution and the area under the curve were obtained using the A-Analyzer software. Quantitative analyses were done after the subtraction of the baseline using the Shirley method.

The percentage of each element detected can be determined with Equation (2), where $\% n_{i}$ is the atomic percentage of element $i$.

$$
\% n_{i}=100 n_{i} / \sum n_{1}
$$


$n_{i}$ is also determined by Equation (3), where, the values of each element must be considered.

$$
\% n_{i}=\frac{I_{i j} / \sigma_{i j} K E^{0.7}}{\sum\left(I_{i j} / \sigma_{i j} E K^{0.7}\right)}
$$

$K E$ is the kinetic energy in $\mathrm{eV}, \sigma_{i j}$ and $I_{i j}$ are the Scofield factor and the area under the curve, respectively, for the " $i$ " element of " $j$ " component [39].

\subsection{Fourier-Transform Infrared Spectroscopy (FTIR)}

FTIR measurements were performed with a Perkin-Elmer Spectrum GX (Waltham, MA, USA) in ATR mode. The spectra of powdered CNC were obtained in the transmittance mode by recording 16 scans at a resolution of $4 \mathrm{~cm}^{-1}$, and a frequency range from 4000 to $700 \mathrm{~cm}^{-1}$.

\subsection{X-ray Diffraction (XRD)}

CNC were analyzed with Malvern Instruments XRD Empyrean (Malvern, UK) with $\mathrm{Cu}-\mathrm{K} \alpha$ radiation at $45 \mathrm{kV}$ and a current of $40 \mathrm{~mA}$. The incidence angle was set to $5-70^{\circ}$ (step size of $0.2^{\circ}$ ). The percentage of crystallinity was calculated according to the Rietveld method [40], and the obtained data was analyzed with the University of Trento MAUD 2.1 software (Trento, Italy).

\subsection{Atomic Force Microscope (AFM)}

The morphology of CNC was characterized using Park Systems AFM NX10 (South Korea). CNC dispersions $(0.005 \%$, in water) were sonicated in an ultrasonic bath. Next, $10 \mathrm{~mL}$ of CNC dispersions were transferred to a metal microscope slide and air-dried. CNC images were obtained via tapping mode in the air using Budget Sensors Tap300-G probe (Izgrev, Sofia, Bulgaria). AC160TS-R3 micro silicon tips, coated with aluminum from Oxford Instruments (Abingdon, UK) were used for image recording. The amplitude and height of the samples were obtained from $1 \mu \mathrm{m} \times 1 \mu \mathrm{m}$ images, and a resolution of $512 / 512$ pixels/line. At least $30 \mathrm{CNC}$ were measured and the AFM dimensions ( $\mathrm{L}, \mathrm{H}$, and W) were obtained.

\subsection{Dynamic Light Scattering (DLS) and Z-Potential}

The CNC average size (d) and polydispersity index (PdI) was measured using dynamic light scattering (DLS) from Malvern Instruments Zetasizer Nano Series ZS90 (Malvern, UK). CNC solutions were first sonicated in an Elma P120H ultrasound bath (Singen, Germany), at a frequency of $40 \mathrm{kHz}$ and $30 \%$ power, at room temperature, for $30 \mathrm{~min}$. Subsequently, the second dilution of $\mathrm{CNC}$ was made (1:10 ratio) and sonicated again for $10 \mathrm{~min}$. Between 6 and 18 scans were made for each sample, each scan being the average of 10 repetitions. DLS was used with a dispersant refractive index of 1.33 and absorption index of 0.01 . Z-potential measurements were made using the same diluted samples prepared for DLS, with a disposable capillary cell (DTS1070).

\section{Results}

\subsection{Yield and Factorial Design}

CNC of $A$. tequilana bagasse were prepared using 24 experimental acid hydrolysis conditions ( 12 conditions with $\mathrm{H}_{2} \mathrm{SO}_{4}$ and 12 conditions with $\mathrm{HCl}$ ) (Table 2). The maximum CNC yields obtained were $96 \%$ and $90 \%$ for experimental conditions $\mathrm{E} 8 \mathrm{~S}$ and $\mathrm{E} 8 \mathrm{H}$, respectively. The minimum CNC yields were observed with the experimental conditions E1S and $\mathrm{E} 1 \mathrm{H}$, with values of $4.2 \%$ and $4.5 \%$, respectively. The standardized Pareto plots for CNC-S and $\mathrm{CNC}-\mathrm{H}$ yield showed that any factor or interaction between factors was statistically not significant (Figure S1). The complete list of obtained yields for all experimental is shown in Tables $\mathrm{S} 1$ and $\mathrm{S} 2$ for $\mathrm{HCl}$ and $\mathrm{H}_{2} \mathrm{SO}_{4}$, respectively. 


\subsection{Determination of Sulfate Groups in CNC-S}

Figure 1a shows the total sulfate groups, i.e., the residual charge of $\mathrm{H}_{2} \mathrm{SO}_{4}$ on the CNC$\mathrm{S}$ surface, as a function of hydrolysis time for all $\mathrm{H}_{2} \mathrm{SO}_{4}$ hydrolysis experiments. The total content of sulfate groups $\left(C_{S G}\right)$ increased with time, temperature, and acid concentration, exhibiting an exponential behavior of $C_{S G}=a e^{b t}$. The "a" and " $\mathrm{b}$ " equation values are shown in Table 3.

(a)
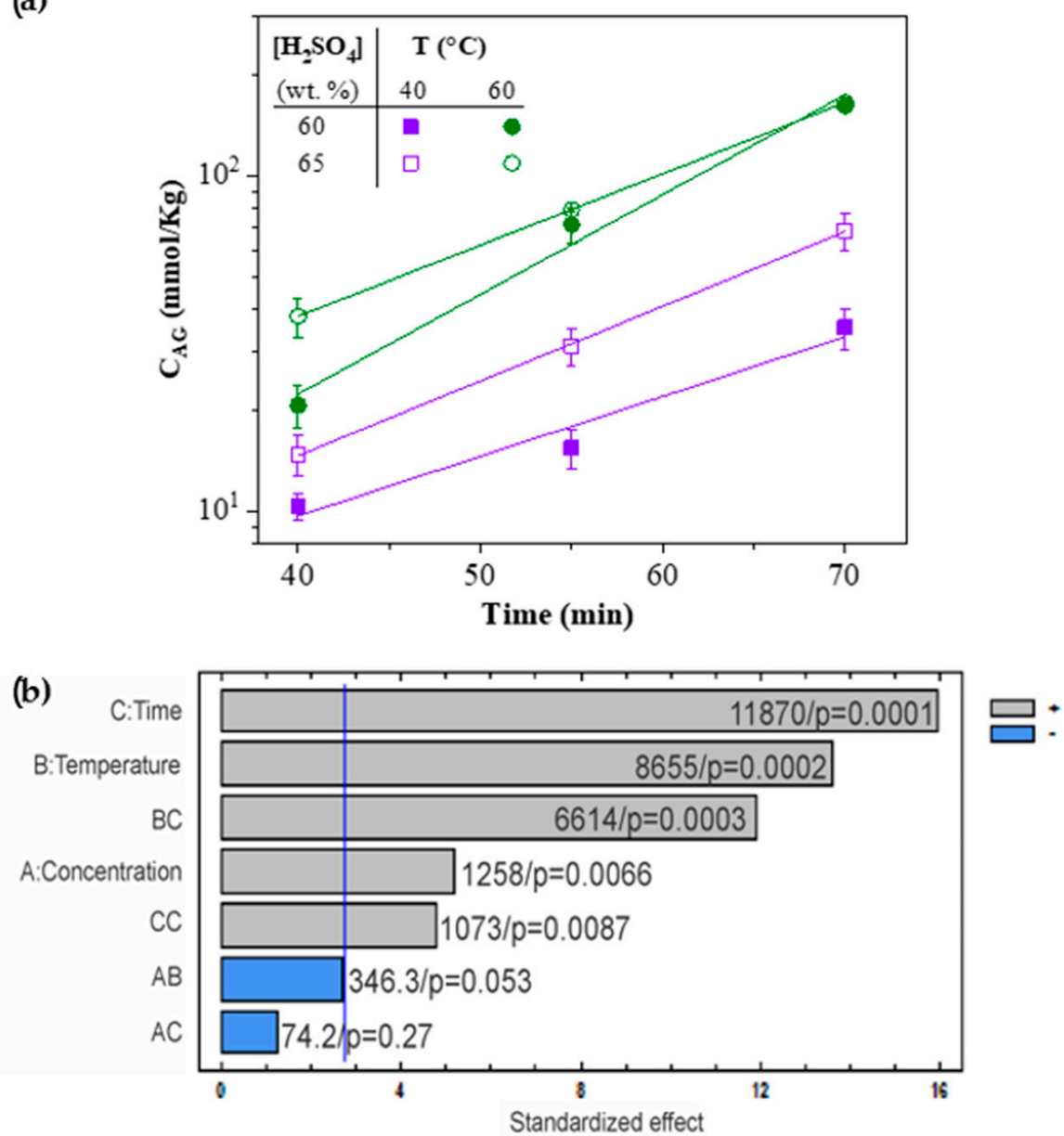

Figure 1. (a) Total sulfate groups content $\left(C_{S G}\right)$ as a function of time, for different temperatures, and $\mathrm{H}_{2} \mathrm{SO}_{4}$ concentrations. The lines represent the exponential equation: $C_{S G}=a e^{b t}$. (b) Standardized Pareto diagram for total sulfate groups present in CNC-S, the sum of squares, and the $p$-value are shown at the right side of each bar.

The principal factors and factor interactions with higher influence are shown in the Pareto diagram (Figure 1b). Positive effects indicate an increase from the minimum level to the maximum, while negative effects imply the opposite [41]. Concentration, time, and temperature are statistically significant factors $(p<0.05)$ contributing to the increase in $C_{S G}$. The highest amount of sulfate groups was quantified for the experimental conditions E7S $(162.0 \mathrm{mmol} / \mathrm{kg})$ and E8S $(166 \mathrm{mmol} / \mathrm{kg})$. The complete list of total sulfate groups content is shown in Table S3. Our results are similar to those obtained for other sources, such as huizache wood $\left(39.78 \mathrm{mmol} / \mathrm{kg}\right.$ with $65 \% \mathrm{H}_{2} \mathrm{SO}_{4}, 45{ }^{\circ} \mathrm{C}$ and 45 min reaction, and $26.9 \mathrm{mmol} / \mathrm{kg}$ with $60 \% \mathrm{H}_{2} \mathrm{SO}_{4}, 55^{\circ} \mathrm{C}$ and $65 \mathrm{~min}$ of reaction) [32]. Interactions $\mathrm{BC}$ (time and temperature) and CC (quadratic time) were also statistically significant $(p<0.05)$, and had a positive effect. 
Table 3. Total sulfate groups content equation parameters.

\begin{tabular}{|c|c|c|c|c|c|c|}
\hline \multirow{2}{*}{$\begin{array}{c}\mathrm{T}\left({ }^{\circ} \mathrm{C}\right) \\
{\left[\mathrm{H}_{2} \mathrm{SO}_{4}\right]} \\
(\mathbf{w t} \%)\end{array}$} & \multicolumn{3}{|c|}{40} & \multicolumn{3}{|c|}{60} \\
\hline & $\begin{array}{c}a \\
(m m o l / k g)\end{array}$ & $\begin{array}{c}\mathbf{b} \\
(1 / \min )\end{array}$ & $\mathbf{R}^{2}$ & $\begin{array}{c}a \\
(m m o l / k g)\end{array}$ & $\begin{array}{c}\mathrm{b} \\
(1 / \min )\end{array}$ & $\mathbf{R}^{2}$ \\
\hline 60 & $1.90 \pm 0.84$ & $0.04 \pm 8 \times 10^{-3}$ & 0.8976 & $1.46 \pm 0.69$ & $0.07 \pm 8 \times 10^{-3}$ & 0.9446 \\
\hline 65 & $1.95 \pm 0.13$ & $0.01 \pm 1 \times 10^{-3}$ & 0.9983 & $5.38 \pm 0.015$ & $0.05 \pm 5 \times 10^{-5}$ & 1.0 \\
\hline
\end{tabular}

\subsection{X-ray Photoelectron Spectroscopy (XPS)}

Soluble-grade cellulose pulp and CNC-S were analyzed by XPS before and after acid hydrolysis at the most severe condition tested (E8S). In the inspection spectrum of solublegrade cellulose (Figure 2a) and CNC-S (Figure 2b), the main peaks are located at 285 and $532 \mathrm{eV}$, corresponding to $\mathrm{C}$ and $\mathrm{O}$ atoms, respectively. In the case of CNC-S, the presence of an $\mathrm{S}$ atom peak at $164 \mathrm{eV}$ is observed, which is a typical feature of $\mathrm{H}_{2} \mathrm{SO}_{4}$ hydrolysis.
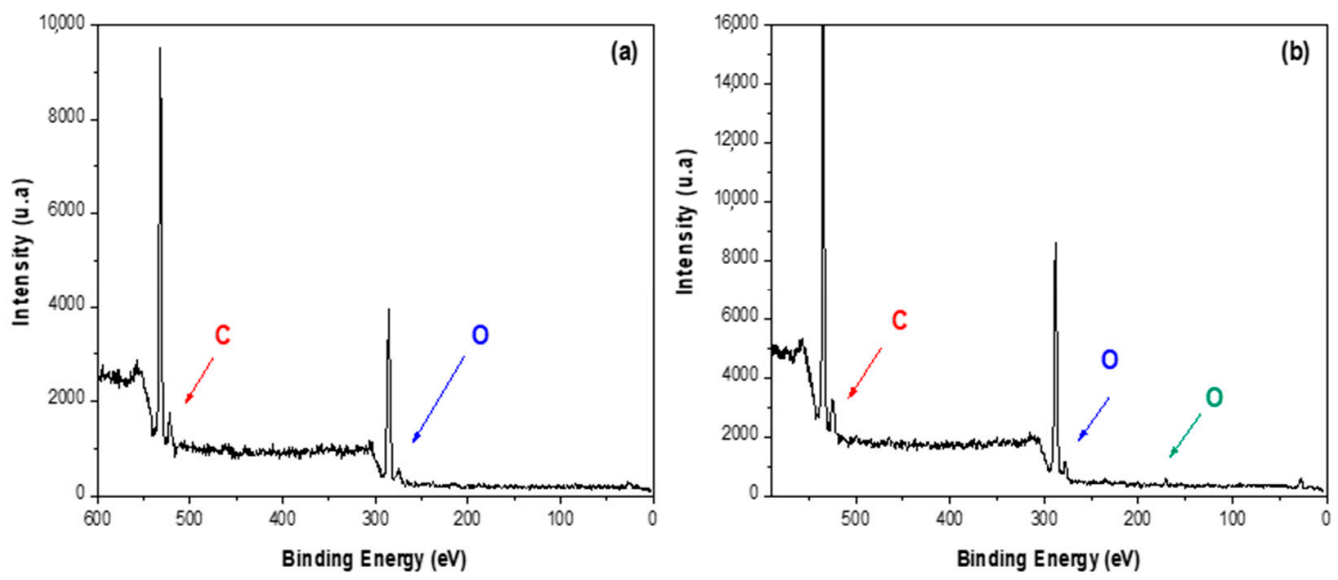

Figure 2. XPS spectrum of (a) soluble-grade cellulose pulp, and (b) CNC-S (E8S).

The deconvolution spectra were performed for C1s (Figure 3a), and O1S (Figure 3b) for soluble-grade cellulose, and C1s (Figure 3c), O1s (Figure 3d), and S2p (Figure 3e) for CNC-S. In the high resolution C1s spectra, the $\mathrm{C}$ signal is resolved into three distinctive peaks for both soluble cellulose and CNC-S, with bond energies at 283, 285, and, $288 \mathrm{eV}$, attributed to $\mathrm{C}-\mathrm{C}, \mathrm{C}-\mathrm{O}, \mathrm{C}-\mathrm{OH}$, and $\mathrm{C}-\mathrm{O}-\mathrm{C}$ bonds, respectively. In the high resolution $\mathrm{O} 1 \mathrm{~s}$ spectra, two peaks were observed at 532 and $533 \mathrm{eV}$, attributed to $\mathrm{O}-\mathrm{H}$ and $\mathrm{O}-\mathrm{C}$ bonds for soluble cellulose spectra. In the $\mathrm{O} 1 \mathrm{~s}$ spectra of $\mathrm{CNC}$, these signals were resolved at peaks 533 and $534 \mathrm{eV}$, due to the presence of $\mathrm{S}$ atoms [38]. Due to this shift, the S-O bond is located at a binding energy of $169 \mathrm{eV}$ for S2p.

Table 4 shows the atomic composition of soluble-grade cellulose pulp and CNC-S. After hydrolysis, the total $\mathrm{SO}_{4}$ group content of CNC-S was $4.92 \mathrm{wt} \%$. The stoichiometry of the sample could not be determined, as the $\mathrm{H}$ atom was not detected by the XPS technique. However, the total percentage of $\mathrm{O}$ atoms was higher compared to soluble-grade cellulose due to an increase in $\mathrm{OH}$ bond formation.

The values obtained in the analysis of soluble-grade cellulose pulp ( $\alpha$-cellulose) are similar to the results depicted at the database of the natural polymers manual [42], in where two components for $\mathrm{C} 1 \mathrm{~s}$ are reported, with binding energies of 286.73 and $288.06 \mathrm{eV}$ for the $\mathrm{C}-\mathrm{C}$ and $\mathrm{C}-\mathrm{O}$ bonds, respectively. For O1s spectra, two components at $532.93 \mathrm{eV}$ for the $\mathrm{O}-\mathrm{H}$ bond, and $533.51 \mathrm{eV}$ for the $\mathrm{C}-\mathrm{O}$ are shown. 

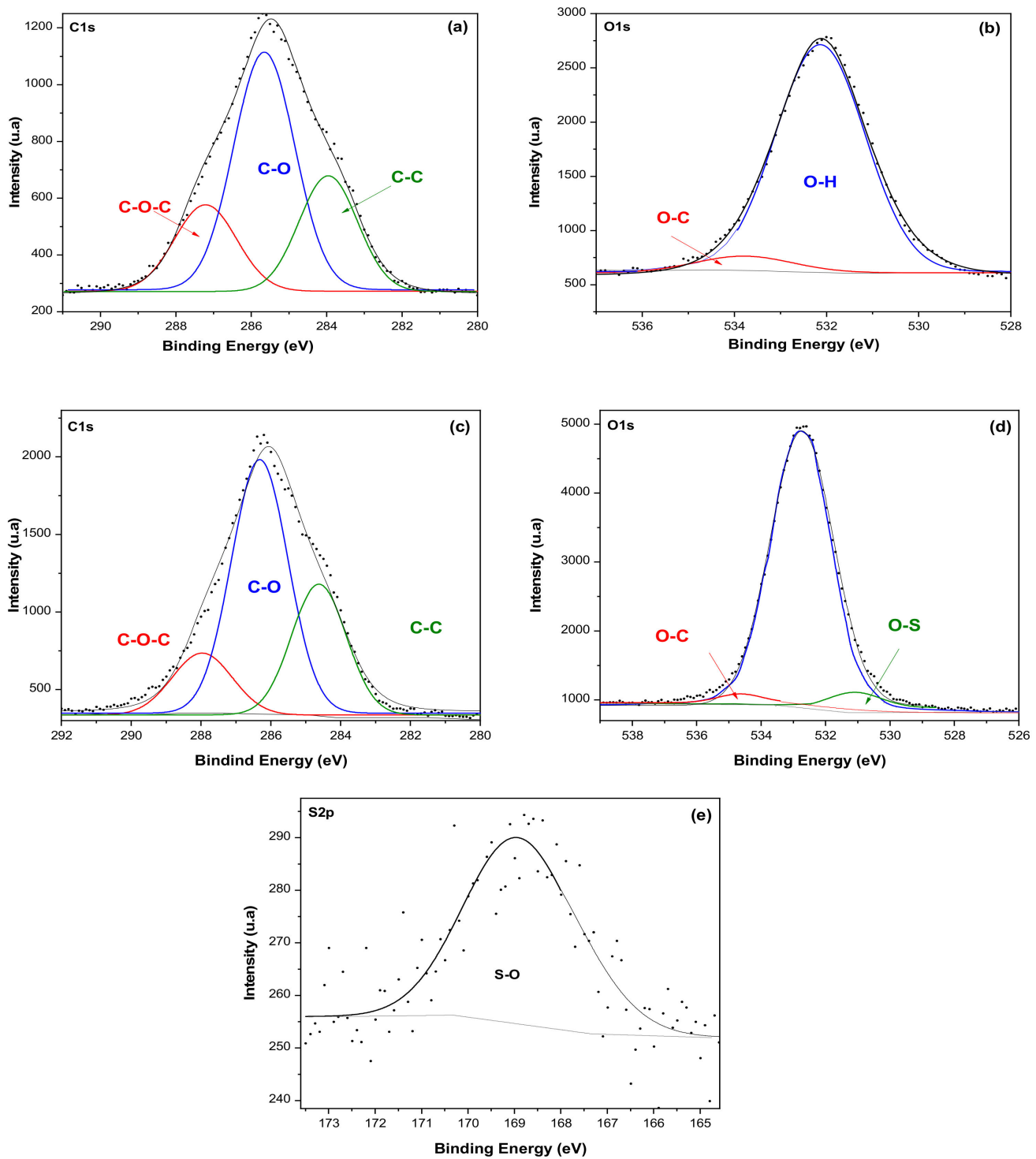

Figure 3. High resolution spectra for soluble-grade cellulose pulp: (a) C1s, (b) O1s, and CNC-S: (c) C1S, (d) O1s, and (e) S2p.

Table 4. XPS atomic composition of soluble-grade cellulose pulp and CNC-S (E8S).

\begin{tabular}{cccccccc}
\hline \multirow{2}{*}{$\begin{array}{c}\text { Sample } \\
\text { Z }\end{array}$} & & \multicolumn{2}{c}{ Soluble-Grade Cellulose Pulp } & \multicolumn{3}{c}{ CNC (E1S) } \\
\cline { 3 - 8 } & & C & Atom \% & Atom \% & C & Atom \% & Atom \% \\
\hline \multirow{2}{*}{ C1s } & C-O-C & 4.51 & 10.96 & & 5.63 & 7.58 & \\
& C-O, C-OH & 12.89 & 31.32 & 57.82 & 23.58 & 31.72 & 56.12 \\
& C-C & 6.40 & 15.54 & & 12.50 & 16.82 & \\
\multirow{2}{*}{ O1s } & O-H & 15.44 & 37.49 & & 25.74 & 34.63 & \\
& O-C & 1.93 & 4.69 & 42.18 & 1.90 & 2.56 & 38.96 \\
& O-S & - & - & & 1.31 & 1.77 & \\
\hline \multirow{2}{*}{ S2p } & S-O & 41.17 & 100 & 0 & 3.66 & 4.92 & 4.92 \\
\hline \multirow{2}{*}{ Total } & & 41.17 & 100 & 100 & 74.33 & 100 & 100 \\
\hline
\end{tabular}




\subsection{Fourier-Transform Infrared Spectroscopy (FTIR)}

Figure 4 shows the comparison of the spectra of soluble-grade cellulose pulp and CNC-S (E10S) and CNC-H (E3H). The obtained spectra showed characteristic frequencies of cellulose, where the vibration bands of $\mathrm{C}-\mathrm{H}$ bonds $\left(2918 \mathrm{~cm}^{-1}\right.$ [asymmetric vibrations], $2851 \mathrm{~cm}^{-1}$ [symmetric vibrations]), and C-H bonds (1360 and $1318 \mathrm{~cm}^{-1}$ [crystal band] $[43,44])$ were observed, the latter being an indicator of the presence of $\mathrm{CNC}$, as the band is associated with the preferential directional arrangement of $\alpha$-cellulose. Bands corresponding to $\mathrm{C}-\mathrm{O}$ bonds (1054 and $1030 \mathrm{~cm}^{-1}$ ) were observed, whereas those at frequencies of $1160 \mathrm{~cm}^{-1}$ were due to asymmetric vibrations ( $\mathrm{C}-\mathrm{O}-\mathrm{C}$ bonds), and $\mathrm{O}-\mathrm{H}$ bonds (broadband between 3600 and $3200 \mathrm{~cm}^{-1}$, as well as bands at 1335 and $1205 \mathrm{~cm}^{-1}$ ). The vibration of the anomeric carbon group of the carbohydrate $C^{1}-\mathrm{H}$ is observed at $898 \mathrm{~cm}^{-1}$ and the band corresponding to adsorbed water is observed at $1635 \mathrm{~cm}^{-1}[13,45,46]$.

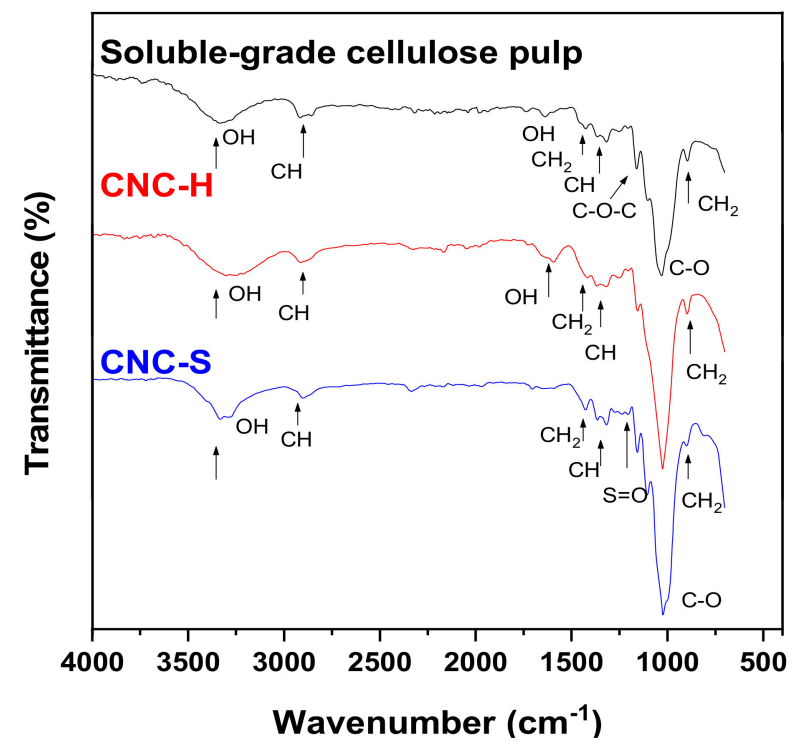

Figure 4. FTIR spectra comparison for soluble-grade cellulose pulp, CNC-H (E10H), and CNC-S (E3S).

The CNC-S spectrum showed a weak sulfur peak at $1202 \mathrm{~cm}^{-1}$, which does not appear in the FTIR spectrum of soluble-grade cellulose pulp. This peak is associated with $\mathrm{S}=\mathrm{O}$ bonds, indicating esterification of the hydroxyl group during acid hydrolysis. On the other hand, a band corresponding to chlorine ions was not observed for $\mathrm{CNC}-\mathrm{H}$, indicating that the hydrolysis with $\mathrm{HCl}$ resulted in hydroxyl groups, which are also present in the soluble-grade cellulose pulp $[20,22]$. The less intense peak located in the region between 3400 and $3200 \mathrm{~cm}^{-1}$ indicated the crystallinity of both $\mathrm{CNC}$, since the hydrogen bond is less flexible in the crystalline structure $[23,47,48]$.

The sensitive region in FTIR for the detection of the crystallinity of cellulosic materials was located between 850 and $1500 \mathrm{~cm}^{-1}$ [47]. The order index is defined by Oconor et al. [47] as the absorbance ratio of the bands detected at wavelengths of 6.9 and $11 \mu$ (1430 and $900 \mathrm{~cm}^{-1}$, known as crystalline and amorphous bands of cellulose) corresponding to vibrations of $\mathrm{CH}_{2}$ (the symmetric and rolling bending, respectively) and is defined as LOI: $\mathrm{A}_{1430} / \mathrm{A}_{900}$ [47,49-54]. The absorbance ratio of 1363 and $2907 \mathrm{~cm}^{-1}$ was attributed to the flexural and stretching vibrations of $\mathrm{C}-\mathrm{H}$ bonds. This relationship is known as the total crystallinity index (TCI: $\mathrm{A}_{1363} / \mathrm{A}_{2907}$ ) [51,54-56]. The hydrogen bonding intensity is reported by several authors $[49,50,52,57]$ as the ratio $\mathrm{A}_{3350} / \mathrm{A}_{1337}$. The lateral (LOI) and total (TCI) crystallinity indices, as well as the hydrogen bond intensity (HBI) for soluble-grade cellulose, were 1.04, 1.06, and 0.87, respectively. As a reference, the values for Whatman paper were 1.21, 0.89, and 0.99, respectively. For CNC-S and CNC-H samples (E1S, E8S, E10S, E3H, and E8H), LOI and TCI values of $1.03 \pm 0.17$ and $1.00 \pm 0.13$ were obtained, similar to those of soluble cellulose. In contrast, the obtained HBI values $(1.14 \pm 0.1)$ were 
slightly higher than that of soluble-grade cellulose pulp. These values were not related to acid nor hydrolysis conditions and were different from those reported for CNC-S obtained from sugar cane bagasse (LOI: 0.57, TCI: 1.32) [51].

\subsection{X-ray Diffraction (XRD)}

Figure 5 shows the diffractograms of the soluble-grade cellulose pulp, CNC-H, and CNC-S. Peaks at $2 \theta$ angles for the three spectra are similar to that reported in the literature for cellulose crystalline allomorphs [13] with main signals at $2 \theta=14.5^{\circ}(101), 16.5^{\circ}$ $\left(\begin{array}{lll}1 & 0 & -1\end{array}\right), 22.4^{\circ}\left(\begin{array}{lll}0 & 0 & 2\end{array}\right)$ and $34.8^{\circ}\left(\begin{array}{lll}0 & 4 & 0\end{array}\right)$ [58]. The curves showed peaks associated with cellulose corresponding to the crystalline planes, which are present in all cases with different intensity and broadening. A very common assumption is that the increased amorphous region contribution is the main source of peak broadening [44]. However, several factors may influence peak broadenings, such as anisotropy and nanocrystal size [59]. This could explain the peak at $22.4^{\circ}$ for CNC-S and CNC-H, where a slight broadening can be observed at the beginning, which is not observed in the spectra of soluble-grade cellulose pulp.

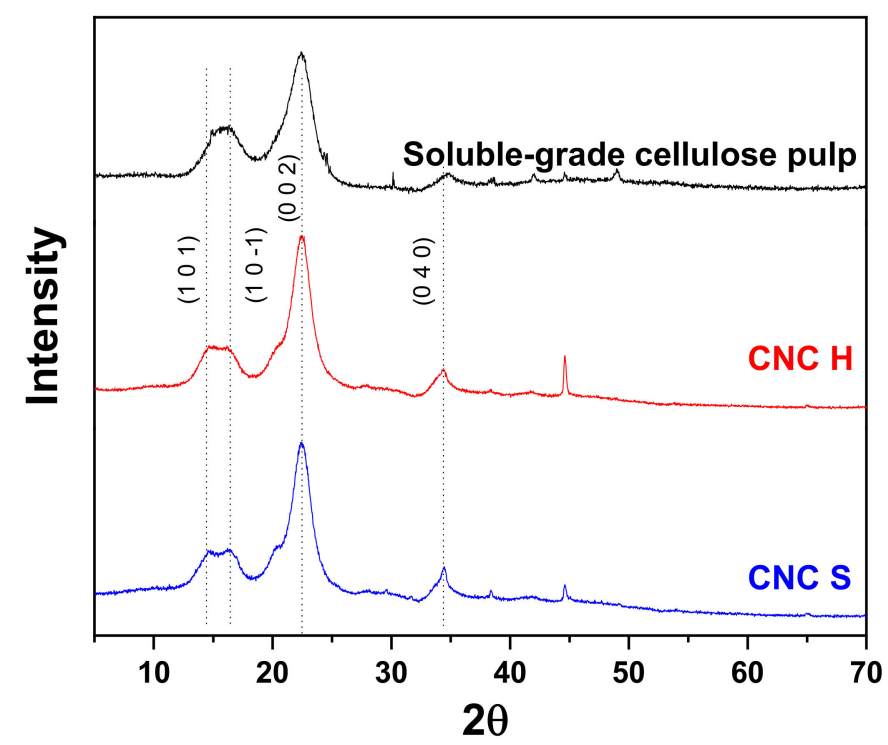

Figure 5. XRD spectra comparison for soluble-grade cellulose pulp, CNC-H (E10H), and CNC-S (E3S).

The crystallinity percentages were calculated with the Rietveld method [40] (Figure S2). The crystallinity values for CNC were recorded for samples E1S (88.4\%), E8S (91.3\%), and E10S (89.7\%), whereas the crystallinity value for CNC-H was recorded for sample E3H $(90.1 \%)$. Compared to a previous work developed by our research group, a crystallinity value of $79.2 \%$ was obtained from soluble-grade cellulose pulp [27]. The values herein reported are higher than those found in the literature for Avicel ${ }^{\circledR} \mathrm{PH}-102$ (51\%) [60], Kraft eucalyptus dry lap pulp (73\%, $\mathrm{H}_{2} \mathrm{SO}_{4}$ concentration of $58 \mathrm{wt} \%$ ) [61], and A. tequilana (TEMPO/NaOCl/NaBr system, 78.5\%) [62].

\subsection{Atomic Force Microscopy (AFM)}

AFM measurements were carried out to measure the length $(\mathrm{L})$, height $(\mathrm{H})$, and width (W) of dry-deposited CNC-H and CNC-S. AFM images of CNC-H are shown in 2D and height histogram for samples E1H (Figure 6a) and E8H (Figure 6b), respectively, and their 3D projection (Figure $6 c, d$, respectively). Long, wide, and non-homogenous crystals were observed for the mildest $(\mathrm{E} 1 \mathrm{H})$ and more severe $(\mathrm{E} 8 \mathrm{H})$ hydrolysis conditions. An average $\mathrm{L}$ of $216 \pm 73$ and $266 \pm 107 \mathrm{~nm}, \mathrm{H}$ of 8.9 and $8.6 \mathrm{~nm}$, and $\mathrm{W}$ of $69 \pm 17$ and $88 \pm 15$ were measured for E1H (mildest condition) and $\mathrm{E} 8 \mathrm{H}$ (severe condition), respectively. For the mildest conditions, CNC-H was thinner and shorter than those obtained with the most severe conditions, but with similar $\mathrm{H}$ values. 
(a)
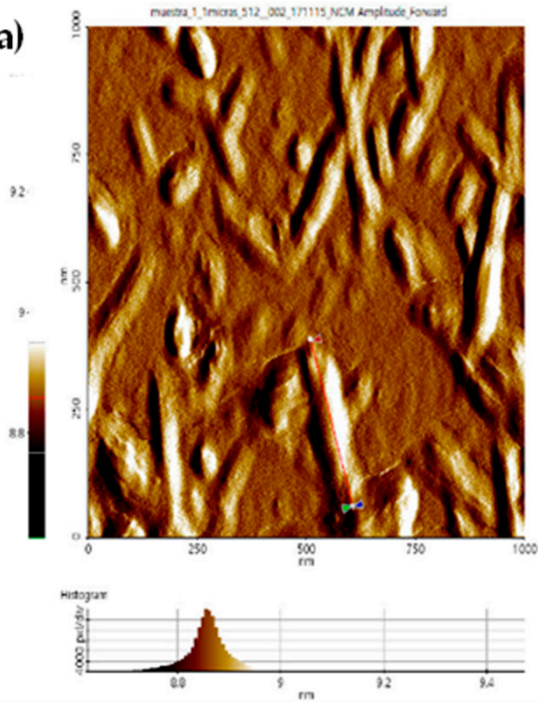

(c)

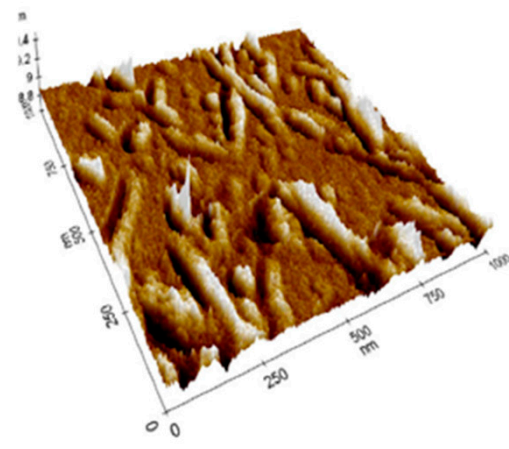

(b)
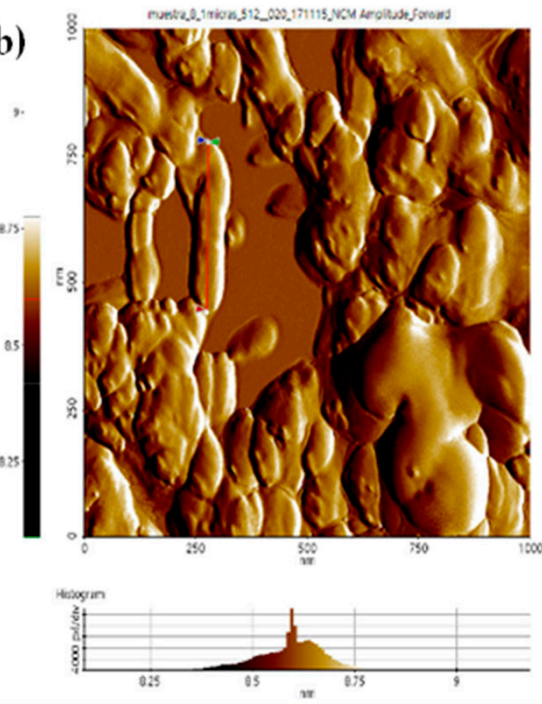

(d)

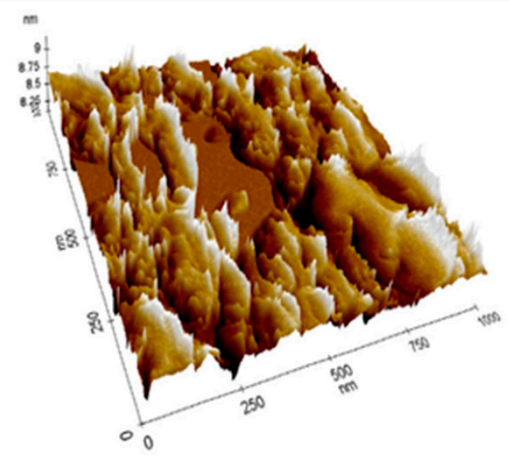

Figure 6. AFM images of CNC-H for two different conditions: (a) 2D image and histogram of E1H, (b) 2D image and histogram of E8H, (c) 3D image of E1H, (d) 3D image of E8H.

For the rest of the $\mathrm{CNC}-\mathrm{H}$ samples, $\mathrm{L}$ diminishes as $\mathrm{HCl}$ concentration increases, with a minimum and maximum $L$ value of 143 and $1100 \mathrm{~nm}$, respectively. In the case of the width, most of the samples exhibit $\mathrm{W}$ values between 52 and $320 \mathrm{~nm}$, and $\mathrm{H}$ values of 8.6 and $9.1 \mathrm{~nm}$. The $\mathrm{L} / \mathrm{H}$ ratios for $\mathrm{CNC}-\mathrm{H}$ obtained with $2 \mathrm{~N} \mathrm{HCl}$ tend to increase with temperature and time, with values ranging from 20 to $98 \mathrm{~nm}$, whereas $\mathrm{L} / \mathrm{H}$ aspect ratio values for $8 \mathrm{~N} \mathrm{HCl}$ are in the range of 30 to 40 , except for the E2H sample. Finally, L/W ratios are between 2.5 to 20, which have a broader range of values due to the different sizes obtained for the CNC-H. The complete set of AFM images of CNC-H are shown in Figure S3 and the average dimensions obtained at different concentrations, temperatures, and hydrolysis times, as well as aspect ratios, are presented in Table S4. A comparison of CNC-H with different raw materials is shown in Table 5. To our knowledge, there is no information regarding the production of $\mathrm{CNC}-\mathrm{H}$ from $A$. tequilana Weber var. Azul. The $\mathrm{L} / \mathrm{D}$ aspect ratio reported in this table is based on the $\mathrm{CNC}-\mathrm{H}$ height $(\mathrm{L} / \mathrm{H})$.

When $\mathrm{W}$ and $\mathrm{H}$ values are similar, $\mathrm{CNC}$ have a cylindrical shape with a circular cross-section. However, our results showed that the cross-section of the nanocrystals is wider than higher, which may correspond to an ellipsoidal shape. In some samples, different $\mathrm{W}$ were observed due to the agglomeration of the deposited CNC, but only notaggregated $\mathrm{CNC}-\mathrm{H}$ were selected to study $\mathrm{L}, \mathrm{W}$, and $\mathrm{H}$ measurements. The low stability and agglomeration of $\mathrm{CNC}-\mathrm{H}$ are expected due to the absence of groups on the surface of these nanocrystals [32]. 
Table 5. Length and diameter comparison of $\mathrm{CNC}-\mathrm{H}$ from different raw sources.

\begin{tabular}{|c|c|c|c|c|c|}
\hline Source & Conditions & Diameter (nm) & Length (nm) & L/D & Reference \\
\hline Agave tequilana & All & $8.6-9.1$ & $216-829$ & $29.9-95.2$ & \\
\hline Weber var. azul & $\mathrm{E} 1 \mathrm{H}\left(2 \mathrm{~N}, 50^{\circ} \mathrm{C}, 50 \mathrm{~min}\right)$ & 8.9 & 216 & 29.9 & This work \\
\hline bagasse & $\mathrm{E} 8 \mathrm{H}\left(8 \mathrm{~N}, 90^{\circ} \mathrm{C}, 115 \mathrm{~min}\right)$ & 8.6 & 266 & 30.9 & \\
\hline MCC & $4 \mathrm{~N}, 80^{\circ} \mathrm{C}, 225 \mathrm{~min}$ & $10-20$ & - & - & [63] \\
\hline MCC & $8 \mathrm{~N}, 110^{\circ} \mathrm{C}, 180 \mathrm{~min}$ & $14-16$ & $200-250$ & $14-15$ & [13] \\
\hline MCC & $6 \mathrm{~N}, 110^{\circ} \mathrm{C}, 180 \mathrm{~min}$ & $10-30$ & $190-250$ & $10-25$ & [22] \\
\hline $\begin{array}{c}\text { Acacia } \\
\text { farnesiana } \mathrm{L} . \\
\text { Willd }\end{array}$ & $\begin{array}{c}2-8 \mathrm{~N}, 50-90{ }^{\circ} \mathrm{C}, 30-200 \\
\min \end{array}$ & - & $100-512$ & - & [32] \\
\hline
\end{tabular}

AFM images of CNC-S for 2D and height histogram for E1S and E8S (Figure 7a,b), and their 3D projection (Figure 7c,d) showed the presence of thin, shorter than $\mathrm{CNC}-\mathrm{H}$, ellipsoidal nanocrystals, with an average L of $404 \pm 30$ and $149 \pm 59 \mathrm{~nm}, \mathrm{H}$ of 9.3 and $9.2 \mathrm{~nm}$, and W of $37 \pm 5$ and $39 \pm 12$ measured for E1S (mildest condition) and E8S (severe condition), respectively.

a)
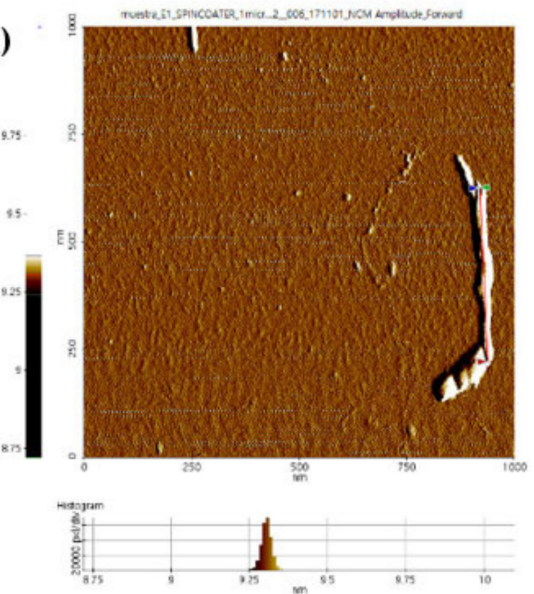

c)

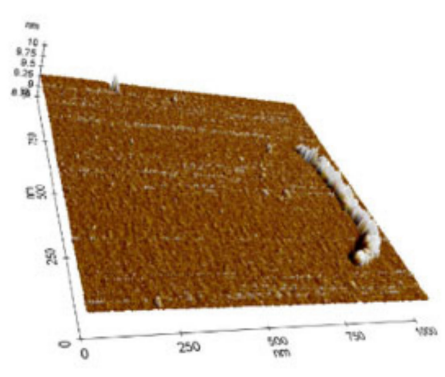

b)
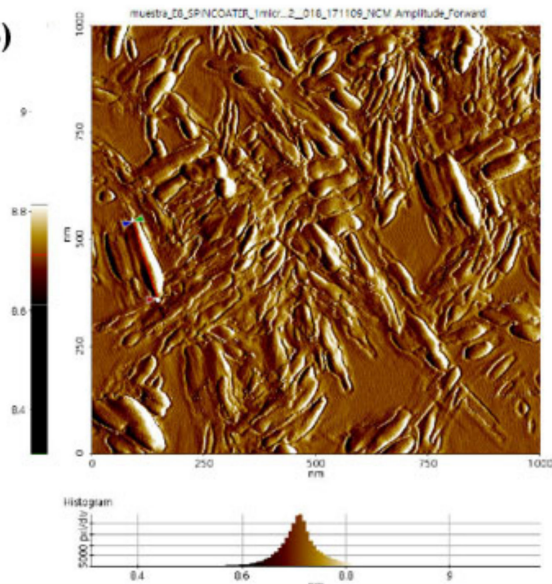

d)

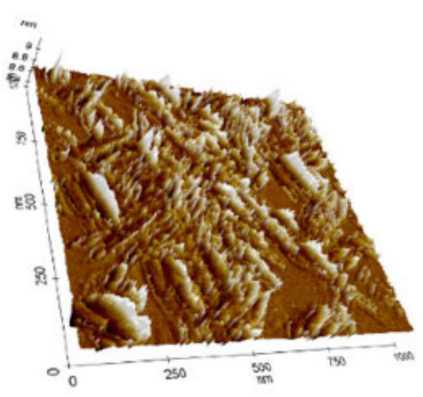

Figure 7. AFM images of CNC-S for two different conditions: (a) 2D image and histogram of E1S, (b) 2D image and histogram of E8S, (c) 3D image of E1S, (d) 3D image of E8S.

For the rest of the CNC-S samples, the $\mathrm{L}$ diminishes as $\mathrm{H}_{2} \mathrm{SO}_{4}$ concentration increases, with a minimum and maximum $L$ value of 88 and $516 \mathrm{~nm}$, respectively. Most of the samples exhibited $W$ values between 20 and $84 \mathrm{~nm}$, and $H$ values of 9.0 and $9.3 \mathrm{~nm}$. The complete set of AFM images of CNC-S are shown in Figure S4 and the AFM dimensions obtained from AFM images are presented in Table S5.

The CNC-S morphology is affected by hydrolysis conditions, and the average $\mathrm{L}$ and $\mathrm{W}$ decreased with increasing hydrolysis time in the hydrolysis process. As hydrolysis time increased, thinner nanocrystals were observed, regardless of acid concentration or temperature. The recorded $W$ values were $73 \pm 11 \mathrm{~nm}, 49 \pm 18 \mathrm{~nm}$, and $33 \pm 7 \mathrm{~nm}$ at 40 , 
55, and 70 min for samples E2S, E10S, and E6S, respectively (Figure S4). A similar pattern was also observed for samples E1S, E9S, and E5S. Increasing temperatures from 40 to $60^{\circ} \mathrm{C}$ diminished $\mathrm{W}$ values from $49 \pm 18$ to $35 \pm 6 \mathrm{~nm}$ for E10S and E12S, respectively. The $\mathrm{W} / \mathrm{H}$ aspect ratio decreased with increasing hydrolysis time, with an average of $4 \pm 1$ (except for the E2S sample, $\mathrm{W} / \mathrm{H}=8$ ). $\mathrm{L} / \mathrm{W}$ aspect ratios had an average between 3.7 and 13 , and tend to decrease with higher acid concentrations. $\mathrm{L} / \mathrm{H}$ aspect ratios had a value between 16-43 and, tend to increase with lower acid concentration, time, and temperatures (Table S5).

The $\mathrm{L} / \mathrm{D}$ aspect ratio reported in Table 6 is based on the CNC-S height $(\mathrm{L} / \mathrm{H})$. For most cellulosic nanomaterials, an $\mathrm{L} / \mathrm{D} \geq 20$ is mentioned [64]. Some of the obtained CNC-S in this work fit into the category of cellulosic nanomaterials. Different CNC-S morphologies obtained from cotton by hydrolysis with $\mathrm{H}_{2} \mathrm{SO}_{4}$ have been reported by Lin and Dufresne (2014) [31], which include circular and ellipsoidal cylindrical shapes as well as flat or laminar shapes. Our results showed that the cross-section of the CNC-S is wider than its high $(\mathrm{W}>\mathrm{H})$, which corresponds to an ellipsoidal shape. The dimensions changed with hydrolysis time, temperature, and acid concentration, therefore the change in morphology could be linked to the total sulfate groups present in the CNC-S surface. As the content of total sulfate groups in the CNC-S increases, $\mathrm{W}$ decreases. The increase in surface groups could avoid interactions between nanocrystals and reduce CNC-S agglomerations.

Table 6. Dimension comparison of CNC-S from different raw sources.

\begin{tabular}{|c|c|c|c|c|c|}
\hline Source & Conditions & Diameter (nm) & Length (nm) & L/D & Reference \\
\hline $\begin{array}{c}\text { Agave } \\
\text { tequilana Weber } \\
\text { var. Azul }\end{array}$ & $\begin{array}{c}\text { All } \\
\text { E1S } \\
\left(60 w t \%, 40^{\circ} \mathrm{C}, 40 \mathrm{~min}\right) \\
\text { E8S } \\
\left(65 w \mathrm{t} \% \mathrm{~N}, 60^{\circ} \mathrm{C}, 70\right. \\
\min )\end{array}$ & $\begin{array}{c}8.7-9.3 \\
9.3 \\
9.2\end{array}$ & $\begin{array}{c}137-404 \\
404 \\
149\end{array}$ & $\begin{array}{c}14.7-44.4 \\
43.4 \\
16.2\end{array}$ & This work \\
\hline $\begin{array}{c}\text { Agave } \\
\text { angustifolia }\end{array}$ & $\begin{array}{c}60 \mathrm{wt} \% \\
45^{\circ} \mathrm{C}, 45 \mathrm{~min}\end{array}$ & $8-15$ & $170-500$ & $10-45$ & [17] \\
\hline $\begin{array}{l}\text { Agave } \\
\text { sisalana }\end{array}$ & $\begin{array}{c}55 \mathrm{wt} \% \\
45-60^{\circ} \mathrm{C}, 20-30 \mathrm{~min}\end{array}$ & $5.9-10.5$ & $177-433$ & $14-15$ & {$[65]$} \\
\hline $\begin{array}{l}\text { Agave } \\
\text { tequilana }\end{array}$ & $\begin{array}{c}65 \mathrm{wt} \% \\
50{ }^{\circ} \mathrm{C}, 60 \mathrm{~min}\end{array}$ & 11 & $323 \pm 112$ & 28 & [15] \\
\hline Barley & $\begin{array}{c}65 \mathrm{wt} \% \\
50{ }^{\circ} \mathrm{C}, 60 \mathrm{~min}\end{array}$ & 10 & $329 \pm 123$ & 32 & [15] \\
\hline MCC & $\begin{array}{c}64 \mathrm{wt} \%, \\
44^{\circ} \mathrm{C}, 130 \mathrm{~min}\end{array}$ & 16 & $218 \pm 56$ & 13 & {$[15]$} \\
\hline$M C C$ & $50{ }^{\circ} \mathrm{C}, 60 \mathrm{~min}$ & $14-16$ & $200-250$ & $14-15$ & [13] \\
\hline $\begin{array}{c}\text { Acacia } \\
\text { farnesiana } \mathrm{L} . \\
\text { Willd }\end{array}$ & $\begin{array}{c}60-65 \mathrm{wt} \% \\
45-55^{\circ} \mathrm{C}, 45-65 \mathrm{~min}\end{array}$ & - & $100-260$ & - & {$[32]$} \\
\hline
\end{tabular}

CNC-S with aspect ratios between 10 to 45 have proven useful for their use as reinforcement materials [16]. Comparing to CNC-S obtained in this work with CNC-S obtained from different natural fibers and raw materials (Table 6), we have observed that tuning the dimensions of the final CNC-S depends solely on the process parameters, rather than on the material origin.

\subsection{Zeta Potential, Dynamic Light Scattering (DLS), and Atomic Force Microscopy (AFM) Comparison}

To determine the stability of the CNC solution, Z-potential measurements were performed as an indicator of the degree of electrostatic repulsion between the charges of the dispersion particles. Particles with absolute values in the $40-60 \mathrm{mV}$ range showed stability, while those with absolute values lower than $30 \mathrm{mV}$ tend to aggregate [66]. The average Z-potential of CNC-S (E8S) showed values of $-54.1 \pm 6.2 \mathrm{mV}$, which is considered stable, 
due to the presence of negative sulfate groups on the surface. For CNC-H (E8H), the average $\mathrm{Z}$ potential value was $-25.1 \pm 0.89 \mathrm{mV}$. CNC-H had lower stability than CNC-S due to the presence of $\mathrm{OH}$ groups on the surface, as observed by AFM. Thus, CNC-H obtained by $\mathrm{HCl}$ hydrolysis show a greater predisposition to agglomerate (Figure 6 and Figure S3). The average Z-potential for the $12 \mathrm{CNC}-\mathrm{H}$ samples was $-23.5 \pm 3 \mathrm{mV}$. In the case of CNC-S at a hydrolysis temperature of $40{ }^{\circ} \mathrm{C}$, the Z-potential values were $<30 \mathrm{mV}$ for two acid concentrations (60 and $65 \%$ ). In contrast, at hydrolysis temperature of $60^{\circ} \mathrm{C}$, the absolute values of Z-potential were $>30 \mathrm{mV}$. The complete list of values for $\mathrm{Z}$ potentials are reported in Table S3.

The CNC particle size obtained by DLS was compared to the L values obtained by $\mathrm{AFM}$, for both acid hydrolysis. The CNC morphology and aspect ratio are also discussed as a function of acid and hydrolysis conditions. The complete list of values of the hydrodynamic diameter (d) and PdI are shown in Tables S1 and S2.

Figure 8a shows the particle size distribution obtained by DLS for CNC-H corresponding to sample $\mathrm{E} 6 \mathrm{H}$. The rest of $\mathrm{CNC}-\mathrm{H}$ samples showed a similar size distribution behavior, which corresponded to a Gaussian type, with a unimodal distribution. For these samples, the polydispersity index (PdI) was on average $0.32 \pm 0.09$. The smallest value was obtained for E12H sample with a hydrodynamic diameter of $323 \pm 18 \mathrm{~nm}$ and a PdI of $0.24 \pm 0.06$, while the highest value was observed for $\mathrm{E} 2 \mathrm{H}$ sample with a hydrodynamic diameter of $794 \pm 245 \mathrm{~nm}$ and a PdI of $0.50 \pm 0.22$.

The size distributions of the CNC-S showed a monomodal distribution at the lowest limit of temperature $\left(40{ }^{\circ} \mathrm{C}\right)$ and time $(40 \mathrm{~min})$ for both acid concentrations $(60$ and 65 $w t \%$, experimental conditions E1S and E2S). The samples showed PDI values of 0.31 and 0.36 for ES1 and ES2, respectively. The experimental setup E4S changed to a bimodal size distribution (Figure 8b), in which two distinctive peaks of $47 \pm 16 \mathrm{~nm}(14 \pm 5 \%)$, and $370 \pm 109 \mathrm{~nm}(78.7 \pm 7 \%)$ were observed for the hydrodynamic diameters. In almost all CNC-S samples, the first peak represented $10-40 \%$ of the signal intensity, with particle sizes between 30 and $100 \mathrm{~nm}$, while the second peak represented $60-90 \%$ of the intensity distribution, with particle sizes between $200-550 \mathrm{~nm}$. Samples are bimodal with PDI average values above $0.66 \pm 0.12$ [67].

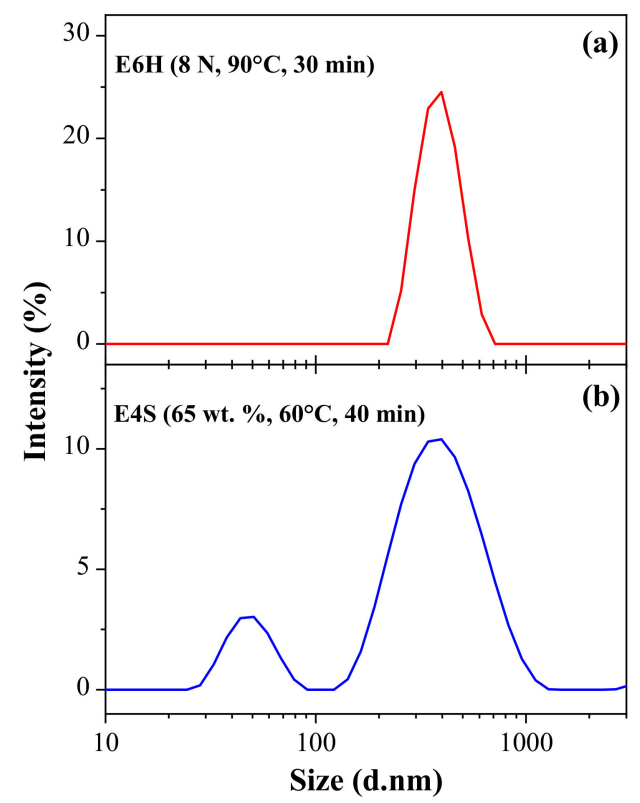

Figure 8. Representative CNC particle size distribution by DLS: (a) CNC-H (E6H) y (b) CNC-S (E4S).

Similar bimodal size distributions were also observed for CNC-S obtained from laser printer paper [68]. The bimodal distribution was due to the presence of different fiber sizes in the paper, and the selected parameters to obtain CNC. In contrast, the bimodal size 
distribution observed for CNC-H and CNC-S from Acacia farneciana L. Willd was attributed to the bleaching process and specific hydrolysis conditions [32]. On the other hand, diprotic acids such as $\mathrm{H}_{2} \mathrm{SO}_{4}$ produce monovalent and divalent ions $\left(\mathrm{HSO}_{4}{ }^{-}\right.$and $\left.\mathrm{SO}_{4}{ }^{-}\right)$, and the composition in aqueous systems depends on the concentration and temperature of the system. This suggests that during hydrolysis, both $\mathrm{HSO}_{4}{ }^{-}$and $\mathrm{SO}_{4}{ }^{=}$ions coexist, which probably can attack pulp in different ways, generating nanocrystals with varied morphologies and dimensions.

Figure 9 shows a comparison of the average particle size of the CNC obtained by DLS and AFM. Larger CNC-H particle sizes were obtained (Figure 9a, 300-800 nm), compared to CNC-S (Figure 9b, 100-500 nm).
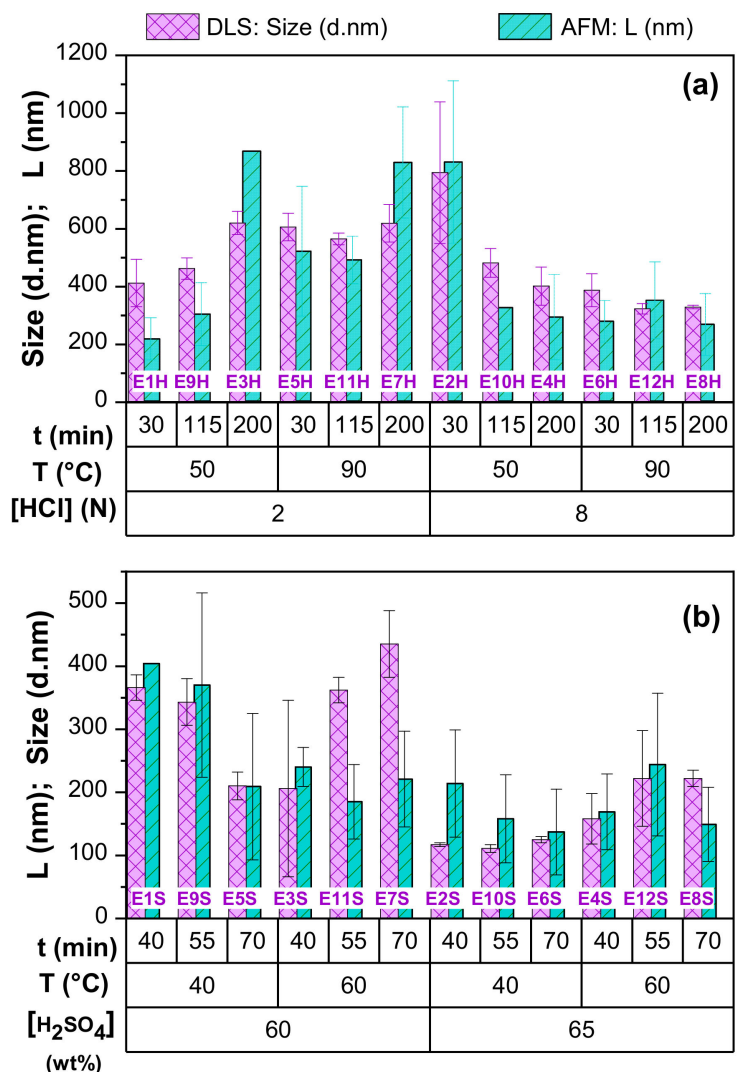

Figure 9. CNC length comparison measured using AFM and DLS for both acid hydrolysis: (a) $\mathrm{CNC}-\mathrm{H}$ (b) CNC-S.

The recorded $\mathrm{L}$ values measured with AFM were relatively similar to the hydrodynamic diameters (d) measured by DLS. As DLS is faster than AFM, it is usually the preferred technique to estimate $\mathrm{CNC}$ lengths obtained from different types of raw materials.

$\mathrm{HCl}$ concentration was a determining factor in the size of the nanocrystals, obtaining smaller sizes when concentrations were higher ( $8 \mathrm{~N}$ ) (Figure 9a). In this case, the hydrodynamic diameters oscillated between $300-500 \mathrm{~nm}$ for $\mathrm{HCl} 8 \mathrm{~N}$, except for the lower limits of temperature $\left(50{ }^{\circ} \mathrm{C}\right)$ and hydrolysis time $(30 \mathrm{~min})$ where the diameter is $829 \pm 282 \mathrm{~nm}$. Lower concentrations of $\mathrm{HCl}(2 \mathrm{~N})$ gave higher hydrodynamic diameters of 450-800 nm. Similarly, CNC-H diameter did not rely on temperature at low concentrations of $\mathrm{HCl}$, with an average size of $570 \pm 164 \mathrm{~nm}$. In contrast, at higher $\mathrm{HCl}$ concentrations, the size decreased with increasing temperature $\left(50\right.$ and $\left.90^{\circ} \mathrm{C}\right)$ and hydrolysis time. Hydrolysis with $\mathrm{H}_{2} \mathrm{SO}_{4}$ gave smaller hydrodynamic diameters than those obtained with $\mathrm{HCl}$ (Figure $9 \mathrm{~b}$ ). The size values reported in this graph corresponded to the average size from their bimodal distribution, which is similar to the longer length of elongated ellipsoids, as demonstrated by AFM 
Figure 10 shows the effect of hydrolysis conditions with $\mathrm{HCl}$ (Figure 10a), and $\mathrm{H}_{2} \mathrm{SO}_{4}$ 60 and $65 \mathrm{wt} \%$ (Figure 10b) on the CNC length measured with AFM.
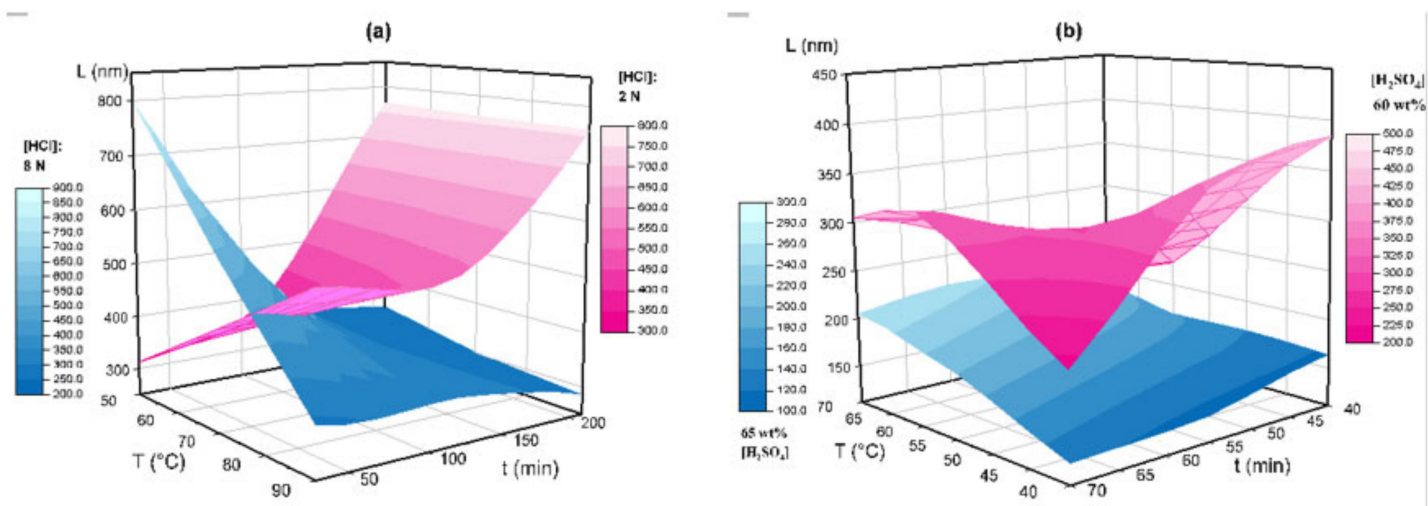

Figure 10. 3D representation of lengths measured by AFM for temperature, time, and different acid conditions: (a) $\mathrm{HCl}$ hydrolysis, 8N (blue), and 2N (magenta); (b) H2SO4 hydrolysis, $65 \mathrm{wt} \%$ (blue) and $60 \mathrm{wt} \%$ (magenta).

In Figure 10a, smaller CNC-H can be obtained at higher acid concentrations $(8 \mathrm{~N})$, with $\mathrm{L}$ values between $270-350 \mathrm{~nm}$, except for $\mathrm{E} 2 \mathrm{H}(829 \pm 282 \mathrm{~nm})$. For lower $\mathrm{HCl}$ concentrations (2N), CNC-H length values increased with hydrolysis time (from 200 to $800 \mathrm{~nm}$ ). A correlation with temperature was not observed. The Pareto analysis (Figure 11a) revealed that concentration and time (AC) was the only statistically significant negative interaction reflecting an inverse relationship, which was also visualized in the 3D representation.

a)

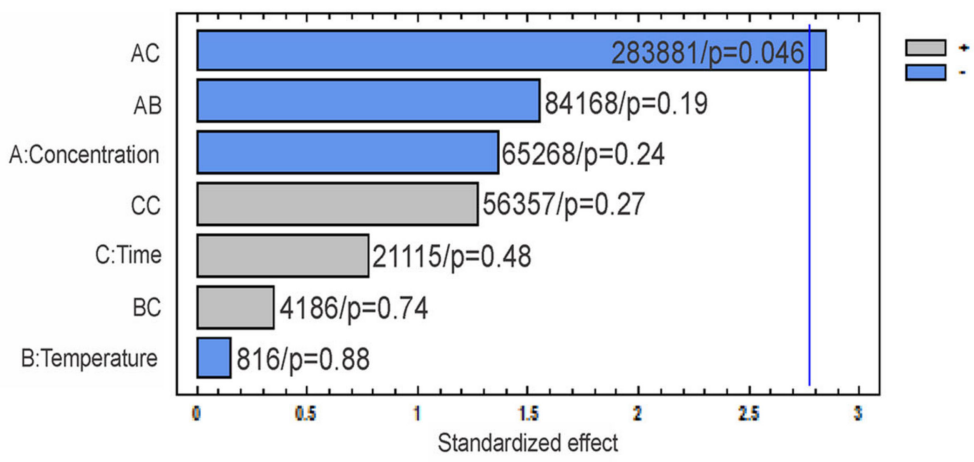

b)

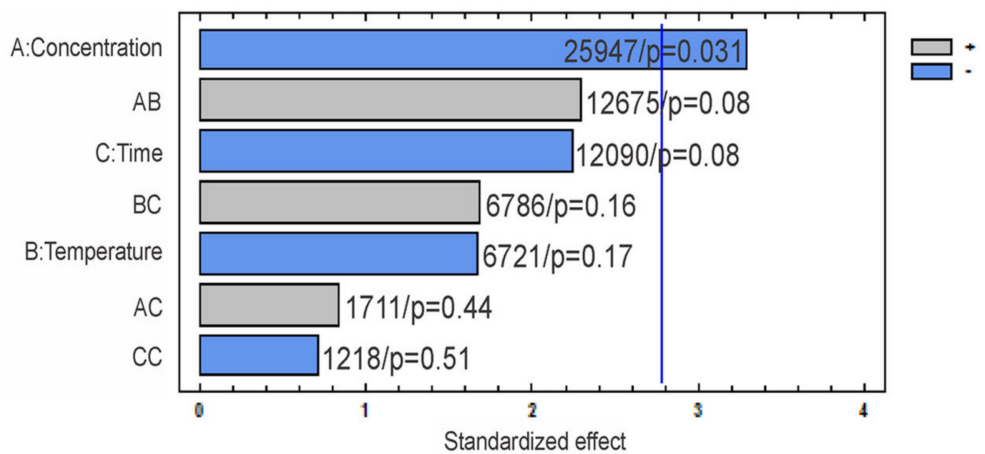

Figure 11. (a) Pareto standardized effect for CNC-H length measured by AFM; (b) Pareto standardized effect for CNC-S length measured by AFM. The sum of squares and $p$-value is shown at the right side of each bar.

The recorded L for CNC-S (Figure 10b) were located between two surfaces, delimited by acid concentration. For $65 \mathrm{wt} \% \mathrm{H}_{2} \mathrm{SO}_{4}$, $\mathrm{L}$ were in the range of $140-250 \mathrm{~nm}$, while for lower concentrations, $\mathrm{L}$ values were in the range of $200-400 \mathrm{~nm}$. A non-linear dependence 
with time and temperature was also observed. The Pareto analysis (Figure 11b) showed that the concentration was the only statistically significant factor contributing to CNC-S length.

\section{Future Research Direction}

In this work, Agave tequilana Weber var. azul bagasse, an agro-industrial waste from the tequila production, represents an alternative, low-cost cellulose source for the formation of CNC. CNC are excellent candidates for their use as composites materials, and low amounts of CNC can improve the final mechanical properties. For example, $0.5 \mathrm{wt} \%$ of CNC-S in PLA polymeric matrices increased by $65 \%$ and $25 \%$ the maximum tensile stress and Young's modulus, respectively [69]. In cementitious matrices, the compressive strength increased by $32 \%$ using $0.35 \mathrm{wt} \% \mathrm{CNC}-\mathrm{S}$ or $0.5 \% \mathrm{CNC}-\mathrm{H}$. The flexural strength value increased by $22 \%$ and $17 \%$ for $0.5 \mathrm{wt} \% \mathrm{CNC}-\mathrm{S}$ and $0.5 \mathrm{wt} \% \mathrm{CNC}-\mathrm{H}$, respectively [70]. The potential use of CNC in cementitious matrices is a novel and promising research area, as there is still scarce information in the literature.

\section{Conclusions}

- $\quad \mathrm{CNC}$ were successfully obtained from soluble-grade cellulose pulp from A. tequilana Weber var. Azul bagasse using an experimental design $2^{3}$ for two acids, $\mathrm{H}_{2} \mathrm{SO}_{4}$ and HCL.

- The maximum CNC yield was 90 and $96 \%$ for CNC-H and CNC-S, respectively, for the most severe hydrolysis conditions tested.

- For CNC-S, the total sulfate group content measured followed an exponential behavior as a function of time: $C_{S G}=a e^{b t}$. The $C_{S G}$ increased with hydrolysis time, temperature, and $\mathrm{H}_{2} \mathrm{SO}_{4}$ concentration. The $C_{S G}$ values ranged from 10 to $150 \mathrm{mmol} / \mathrm{kg}$, depending on the hydrolysis conditions.

- The insertion of sulfate groups on CNC-S was also corroborated using XPS, and the results showed $4.92 \%$ of sulfate groups for E8S. The presence of sulfate groups on CNC-S was also detected by FTIR.

- The FTIR spectra showed LOI and TOI similar to those of soluble-grade cellulose pulp, near to 1 in both cases $(1.03 \pm 0.17$ and $1.00 \pm 0.13$ respectively), while HBI increased about $30 \%$.

- $\quad$ The CNC crystallinity was obtained by XRD using the Rietveld method. For all the analyzed samples, the crystallinity values ranged from 88.4 to $91.3 \%$, while the value for soluble grade cellulose pulp was $79.2 \%$

- The Pareto analysis revealed that $\mathrm{HCl}$ concentration and time factor interaction (AC) is statistically significant on CNC-H length, whereas $\mathrm{H}_{2} \mathrm{SO}_{4}$ concentration is the only statistically significant factor for CNC-S length.

- The CNC lengths obtained by AFM are very similar to the diameter (d) obtained using DLS.

- The CNC-S lengths were shorter and thinner than those of $\mathrm{CNC}-\mathrm{H}$, probably attributed to sulfate group insertion and less agglomeration of the nanocrystals in dispersion.

- The smallest CNC-H length was observed with $8 \mathrm{~N} \mathrm{HCl}(266-350 \mathrm{~nm}$, except for sample E2H), and the longest CNC-H was obtained with $2 \mathrm{~N} \mathrm{HCl}(256-867 \mathrm{~nm})$. The smallest CNC-S length was obtained with $65 \mathrm{wt} \% \mathrm{H}_{2} \mathrm{SO}_{4}(137-244 \mathrm{~nm})$ and the longest CNC-S was obtained with 60 wt. $\% \mathrm{H}_{2} \mathrm{SO}_{4}(185-404 \mathrm{~nm})$.

- As the obtained $\mathrm{CNC}$ have an ellipsoidal shape, the studied dimensions were $\mathrm{L}, \mathrm{H}$, and $\mathrm{W}$. For both acids (H2SO4 and $\mathrm{HCl}$ ), $\mathrm{CNC}$ height ranged between 8.6-9.3 nm, whereas the width ranged between $20-85 \mathrm{~nm}$, and $47-300 \mathrm{~nm}$, for CNC-S, and CNC-H, respectively. Considering that 2 of 3 dimensions are in the nanometer range, the $\mathrm{CNC}$ obtained in this work can be considered as nanomaterials.

- Owing to their exceptional mechanical properties, CNC are excellent candidates to be used as reinforcement materials. 
Supplementary Materials: The following are available online at https:/ /www.mdpi.com/2079-499 1/11/2/520/s1, Figure S1. (a) Pareto standardized effect for CNC-H yield production; (b) Pareto standardized effect for CNC-S yield production. The sum of squares and $p$-value is shown at the right side of each bar; Figure S2. Rietveld analysis for (a) CNC-S (E3S), (b) CNC-H (E10H); Figure S3. AFM 2D images of the 12 CNC-H samples; Figure S4. AFM 2D images of the 12 CNC-S samples; Table S1. DLS and yield results for CNC-H production; Table S2. DLS and yield results for CNC-S production; Table S3. Total sulfate groups of CNC-S; Table S4. AFM measurements of CNC-H; Table S5. AFM measurements of CNC-S.

Author Contributions: Conceptualization, J.A.H., and S.G.E.; methodology, M.A.G.-S., and E.R.M.-B.; software, R.R.C.; validation, E.R.M.-B.; formal analysis, M.A.G.-S., T.D.-V., L.C.R.-R., and E.R.M.B.; investigation, M.A.G.-S., A.B.N.-H., R.R.C., and E.B.F.-O.; resources, J.F.A.S.M.; data curation, M.A.G.-S., T.D.-V., L.C.R.-R., and E.R.M.-B.; writing—original draft preparation, M.A.G.-S., T.D.-V., L.C.R.-R., and E.R.M.-B.; writing-review and editing, M.A.G.-S., T.D.-V., L.C.R.-R., and E.R.M.-B.; visualization, E.R.M.-B., and J.F.A.S.M.; supervision, E.R.M.-B., and J.F.A.S.M.; project administration, E.R.M.-B., and J.F.A.S.M.; funding acquisition, E.R.M.-B., J.A.H., and J.F.A.S.M. All authors have read and agreed to the published version of the manuscript.

Funding: The authors would like to thank Secretaría de Educación Pública (SEP) for financially supporting the project "Development and innovation in nanomaterials and nanocomposites, from the International Thematic Network", call 2015, and Consejo Nacional de Ciencia y Tecnología (CONACyT) for financially supporting Grant No. 334914 (M.A.G.-S. CVU: 632616) and Grant No. 889199 (A.B.N.-H. CVU: 889199). We gratefully recognize a postdoctoral fellowship for T.D.-V. from postdoctoral grants SEP-SES (23-007-C).

Data Availability Statement: The data that supports the findings of this study are available from the corresponding author, E.R.M.-B., upon reasonable request.

Acknowledgments: The authors would like to thank ITRANS (CUCEI, UdG) for the XRD characterization, and the XPS Laboratory (CUCEI, UdG, CONACyT infrastructure Grant 270662).

Conflicts of Interest: The authors declare no conflict of interest.

\section{References}

1. Grishkewich, N.; Mohammed, N.; Tang, J.; Tam, K.C. Recent advances in the application of cellulose nanocrystals. Curr. Opin. Colloid Interface Sci. 2017, 29, 32-45. [CrossRef]

2. Lin, N.; Dufresne, A. Nanocellulose in biomedicine: Current status and future prospect. Eur. Polym. J. 2014, 59, 302-325. [CrossRef]

3. Yu, H.; Qin, Z.; Liang, B.; Liu, N.; Zhou, Z.; Chen, L. Facile extraction of thermally stable cellulose nanocrystals with a high yield of 93\% through hydrochloric acid hydrolysis under hydrothermal conditions. J. Mater. Chem. A 2013, 1, 3938-3944. [CrossRef]

4. Leung, A.C.W.; Lam, E.; Chong, J.; Hrapovic, S.; Luong, J.H.T. Reinforced plastics and aerogels by nanocrystalline cellulose. J. Nanoparticle Res. 2013, 15, 1-24. [CrossRef]

5. Azizi Samir, M.A.S.; Alloin, F.; Sanchez, J.Y.; Dufresne, A. Cellulose nanocrystals reinforced poly(oxyethylene). Polymer 2004, 45, 4149-4157. [CrossRef]

6. Brinchi, L.; Cotana, F.; Fortunati, E.; Kenny, J.M. Production of nanocrystalline cellulose from lignocellulosic biomass: Technology and applications. Carbohydr. Polym. 2013, 94, 154-169. [CrossRef]

7. Kaushik, M.; Moores, A. Review: Nanocelluloses as versatile supports for metal nanoparticles and their applications in catalysis. Green Chem. 2016, 18, 622-637. [CrossRef]

8. Saeed, A.A.; Abbas, M.N.; Singh, B.; Abou-Zeid, R.E.; Kamel, S. Cellulose nanocrystals decorated with gold nanoparticles immobilizing GOx enzyme for non-invasive biosensing of human salivary glucose. Anal. Methods 2019, 11, 6073-6083. [CrossRef]

9. Mohammadkazemi, F.; Doosthoseini, K.; Ganjian, E.; Azin, M. Manufacturing of bacterial nano-cellulose reinforced fiber-cement composites. Constr. Build. Mater. 2015, 101, 958-964. [CrossRef]

10. Cao, Y.; Tian, N.; Bahr, D.; Zavattieri, P.D.; Youngblood, J.; Moon, R.J.; Weiss, J. The influence of cellulose nanocrystals on the microstructure of cement paste. Cem. Concr. Compos. 2016, 74, 164-173. [CrossRef]

11. Fu, T.; Montes, F.; Suraneni, P.; Youngblood, J.; Weiss, J. The Influence of Cellulose Nanocrystals on the Hydration and Flexural Strength of Portland Cement Pastes. Polymers 2017, 9, 424. [CrossRef]

12. Parveen, S.; Rana, S.; Ferreira, S.; Filho, A.; Fangueiro, R. Ultrasonic dispersion of micro crystalline cellulose for developing cementitious composites with excellent strength and stiffness. Ind. Crops Prod. 2018, 122, 156-165. [CrossRef]

13. Yu, H.Y.; Qin, Z.Y.; Liu, L.; Yang, X.G.; Zhou, Y.; Yao, J.M. Comparison of the reinforcing effects for cellulose nanocrystals obtained by sulfuric and hydrochloric acid hydrolysis on the mechanical and thermal properties of bacterial polyester. Compos. Sci. Technol. 2013, 87, 22-28. [CrossRef] 
14. Jemaa, N.; Paleologou, M.; Zhang, X.; Repoit, I.S. Fractionation of a Waste Liquor Stream from Nanocrystalline Cellulose Production. U.S. Patent 8,709,203 B2, 29 April 2014.

15. Espino, E.; Cakir, M.; Domenek, S.; Román-Gutiérrez, A.D.; Belgacem, N.; Bras, J. Isolation and characterization of cellulose nanocrystals from industrial by-products of Agave tequilana and barley. Ind. Crops Prod. 2014, 62, 552-559. [CrossRef]

16. Dhar, P.; Bhasney, S.M.; Kumar, A.; Katiyar, V. Acid functionalized cellulose nanocrystals and its effect on mechanical, thermal, crystallization and surfaces properties of poly (lactic acid) bionanocomposites films: A comprehensive study. Polymer 2016, 101, 75-92. [CrossRef]

17. Rosli, N.A.; Ahmad, I.; Abdullah, I. Isolation and characterization of cellulose nanocrystals from agave angustifolia fibre. BioResources 2013, 8, 1893-1908. [CrossRef]

18. Roman, M.; Winter, W.T. Effect of sulfate groups from sulfuric acid hydrolysis on the thermal degradation behavior of bacterial cellulose. Biomacromolecules 2004, 5, 1671-1677. [CrossRef]

19. Dong, X.M.; Revol, J.F.; Gray, D.G. Effect of microcrystallite preparation conditions on the formation of colloid crystals of cellulose. Cellulose 1998, 5, 19-32. [CrossRef]

20. Beck-Candanedo, S.; Roman, M.; Gray, D.G. Effect of Reaction Conditions on the Properties and Behavior of Wood Cellulose Nanocrystal Suspensions. Biomacromolecules 2005, 6, 1048-1054. [CrossRef]

21. Elazzouzi-Hafraoui, S.; Nishiyama, Y.; Putaux, J.-L.; Heux, L.; Dubreuil, F.; Rochas, C. The Shape and Size Distribution of Crystalline Nanoparticles Prepared by Acid Hydrolysis of Native Cellulose. Biomacromolecules 2008, 9, 57-65. [CrossRef]

22. Cheng, M.; Qin, Z.; Chen, Y.; Hu, S.; Ren, Z.; Zhu, M. Efficient Extraction of Cellulose Nanocrystals through Hydrochloric Acid Hydrolysis Catalyzed by Inorganic Chlorides under Hydrothermal Conditions. ACS Sustain. Chem. Eng. 2017, 5, 4656-4664. [CrossRef]

23. Montanari, S.; Roumani, M.; Heux, L.; Vignon, M.R. Topochemistry of Carboxylated Cellulose Nanocrystals Resulting from TEMPO-Mediated Oxidation. Macromolecules 2005, 38, 1665-1671. [CrossRef]

24. Yu, H.Y.; Qin, Z.Y.; Sun, B.; Yan, C.F.; Yao, J.M. One-pot green fabrication and antibacterial activity of thermally stable corn-like CNC/Ag nanocomposites. J. Nanoparticle Res. 2014, 16, 1-12. [CrossRef]

25. Consejo Regulador del Tequila (CRT), Información Estadística 2020. Available online: https://www.crt.org.mx/EstadisticasCRTweb / (accessed on 20 October 2020).

26. Huitrón, C.; Pérez, R.; Sánchez, A.; Lappe, P.; Zavaleta, L.R. Agricultural waste from the tequila industry as substrate for the production of commercially important enzymes. J. Environ. Biol. 2008, 1, 37-41.

27. Gallardo-Sánchez, M.A.; Hernández, J.A.; Casillas, R.R.; Vázquez, J.I.E.; Hernández, D.E.; Martínez, J.F.A.S.; Enríquez, S.G.; Balleza, E.R.M. Obtaining Soluble-grade cellulose pulp from Agave tequilana Weber var. Azul Bagasse. BioResources 2019, 14, 9867-9881. [CrossRef]

28. Ponce-Reyes, C.E.; Chanona-Pérez, J.J.; Garibay-Febles, V.; Palacios-González, E.; Karamath, J.; Terrés-Rojas, E.; CalderónDomínguez, G. Preparation of cellulose nanoparticles from agave waste and its morphological and structural characterization. Rev. Mex. Ing. Quim. 2014, 13, 897-906.

29. Pech-Cohuo, S.C.; Canche-Escamilla, G.; Valadez-González, A.; Fernández-Escamilla, V.V.A.; Uribe-Calderon, J. Production and Modification of Cellulose Nanocrystals from Agave tequilana Weber Waste and Its Effect on the Melt Rheology of PLA. Int. J. Polym. Sci. 2018, 2018, 1-14. [CrossRef]

30. Lu, H.; Gui, Y.; Zheng, L.; Liu, X. Morphological, crystalline, thermal and physicochemical properties of cellulose nanocrystals obtained from sweet potato residue. Food Res. Int. 2013, 50, 121-128. [CrossRef]

31. Lin, N.; Dufresne, A. Surface chemistry, morphological analysis and properties of cellulose nanocrystals with gradiented sulfation degrees. Nanoscale 2014, 6, 5384-5393. [CrossRef]

32. Ramírez Casillas, R.; del Carmen López López, M.; Becerra Aguilar, B.; Dávalos Olivares, F.; Satyanarayana, K.G. Preparation and Characterization of Cellulose Nanocrystals using Soluble Grade Cellulose from Acid Hydrolysis of Huizache (Acacia farnesiana L. Willd.). BioResources 2019, 14, 3319-3338.

33. Elhalil, A.; Tounsadi, H.; Elmoubarki, R.; Mahjoubi, F.Z.; Farnane, M.; Sadiq, M.; Abdennouri, M.; Qourzal, S.; Barka, N. Factorial experimental design for the optimization of catalytic degradation of malachite green dye in aqueous solution by Fenton process. Water Resour. Ind. 2016, 15, 41-48. [CrossRef]

34. Erper, I.; Turkkan, M.; Odabas, M.S. The mathematical approach to the effect of potassium bicarbonate on mycelial growth of Sclerotinia sclerotiorum and Rhizoctonia solani in vitro. Zemdirbyste= Agriculture 2011, 98, 195-204.

35. Filson, P.B.; Dawson-Andoh, B.E. Sono-chemical preparation of cellulose nanocrystals from lignocellulose derived materials. Bioresour. Technol. 2009, 100, 2259-2264. [CrossRef]

36. Bondeson, D.; Mathew, A.; Oksman, K. Optimization of the isolation of nanocrystals from microcrystalline cellulose by acid hydrolysis. Cellulose 2006, 13, 171-180. [CrossRef]

37. Ramirez Casillas, R.; del Carmen López López, M.; Becerra Aguilar, B.; Dávalos Olivares, F.; Satyanarayana, K.G. Obtaining dissolving grade cellulose from the huizache (Acacia farnesiana L. Willd.) plant. BioResources 2019, 14, 3301-3318. [CrossRef]

38. Vickerman, J.C.; Gilmore, I.S. Surface Analysis—The Principal Techniques; Vickerman, J.C., Gilmore, I.S., Eds.; John Wiley \& Sons, Ltd.: Chichester, UK, 2009; ISBN 9780470721582.

39. Briggs, D.; Seah, M.P. Practical Surface Analysis: Auger and X-ray Photoelectron Spectroscopy, 2nd ed.; Briggs, D., Seah, M.P., Eds.; John Wiley and Sons Ltd.: New York, NY, USA, 1996; ISBN 0471953407. 
40. Snyder, R.L. Analytical profile fitting of X-ray powder diffraction profiles in Rietveld analysis. In The Rietveld Method; Oxford University Press: Oxford, UK, 1993; Volume 1, pp. 111-131. ISBN 0198555776.

41. Antoy, J. Design of Experiments for Engineers and Scientists, 2nd ed.; Elsevier Ltd.: Amsterdam, The Netherlands, 2014; ISBN 9780080994178.

42. Beamson, G.; Briggs, D. High Resolution XPS of Organic Polymers: The Scienta ESCA300 Database; John Wiley and Sons Ltd.: New York, NY, USA, 1992; ISBN 0471935921.

43. Xu, F.; Yu, J.; Tesso, T.; Dowell, F.; Wang, D. Qualitative and quantitative analysis of lignocellulosic biomass using infrared techniques: A mini-review. Appl. Energy 2013, 104, 801-809. [CrossRef]

44. Robles, E.; Fernández-Rodríguez, J.; Barbosa, A.M.; Gordobil, O.; Carreño, N.L.V.; Labidi, J. Production of cellulose nanoparticles from blue agave waste treated with environmentally friendly processes. Carbohydr. Polym. 2018, 183, 294-302. [CrossRef]

45. Anwar, B.; Bundjali, B.; Arcana, I.M. Isolation of Cellulose Nanocrystals from Bacterial Cellulose Produced from Pineapple Peel Waste Juice as Culture Medium. Procedia Chem. 2015, 16, 279-284. [CrossRef]

46. Contreras, H.J.; Trujillo, H.A.; Arias, G.; Pérez, J.; Delgado, E. Espectroscopia Atr-Ftir De Celulosa: Aspecto Instrumental Y Tratamiento Matemático De Espectros. e-Gnosis 2010, 8, 1-13.

47. O'Connor, R.T.; DuPré, E.F.; Mitcham, D. Applications of Infrared Absorption Spectroscopy to Investigations of Cotton and Modified Cottons. Text. Res. J. 1958, 28, 382-392. [CrossRef]

48. Lu, P.; Hsieh, Y.-L. Preparation and characterization of cellulose nanocrystals from rice straw. Carbohydr. Polym. 2012, 87, 564-573. [CrossRef]

49. Poletto, M.; Ornaghi, H.; Zattera, A. Native Cellulose: Structure, Characterization and Thermal Properties. Materials 2014, 7, 6105-6119. [CrossRef] [PubMed]

50. Oh, S.Y.; Yoo, D.I.; Shin, Y.; Kim, H.C.; Kim, H.Y.; Chung, Y.S.; Park, W.H.; Youk, J.H. Crystalline structure analysis of cellulose treated with sodium hydroxide and carbon dioxide by means of X-ray diffraction and FTIR spectroscopy. Carbohydr. Res. 2005, 340, 2376-2391. [CrossRef]

51. Kumar, A.; Singh Negi, Y.; Choudhary, V.; Kant Bhardwaj, N. Characterization of Cellulose Nanocrystals Produced by AcidHydrolysis from Sugarcane Bagasse as Agro-Waste. J. Mater. Phys. Chem. 2020, 2, 1-8. [CrossRef]

52. Kruer-Zerhusen, N.; Cantero-Tubilla, B.; Wilson, D.B. Characterization of cellulose crystallinity after enzymatic treatment using Fourier transform infrared spectroscopy (FTIR). Cellulose 2018, 25, 37-48. [CrossRef]

53. Hurtubise, F.G.; KrÄSSIG, H. Classification of Fine Structural Characteristics in Cellulose by Infrared Spectroscopy Use of Potassium Bromide Pellet Technique. Anal. Chem. 1960, 32, 177-181. [CrossRef]

54. Carrillo, F.; Colom, X.; Suñol, J.; Saurina, J. Structural FTIR analysis and thermal characterisation of lyocell and viscose-type fibres. Eur. Polym. J. 2004, 40, 2229-2234. [CrossRef]

55. Nelson, M.L.; O'Connor, R.T. Relation of certain infrared bands to cellulose crystallinity and crystal lattice type. Part II. A new infrared ratio for estimation of crystallinity in celluloses I and II. J. Appl. Polym. Sci. 1964, 8, 1325-1341. [CrossRef]

56. Nelson, M.L.; O'Connor, R.T. Relation of certain infrared bands to cellulose crystallinity and crystal latticed type. Part, I. Spectra of lattice types I, II, III and of amorphous cellulose. J. Appl. Polym. Sci. 1964, 8, 1311-1324. [CrossRef]

57. Mariano, M.; El Kissi, N.; Dufresne, A. Cellulose nanocrystals and related nanocomposites: Review of some properties and challenges. J. Polym. Sci. Part B Polym. Phys. 2014, 52, 791-806. [CrossRef]

58. Tronc, E.; Hernández-Escobar, C.A.; Ibarra-Gómez, R.; Estrada-Monje, A.; Navarrete-Bolaños, J.; Zaragoza-Contreras, E.A. Blue agave fiber esterification for the reinforcement of thermoplastic composites. Carbohydr. Polym. 2007, 67, 245-255. [CrossRef]

59. Popa, N.C.; Balzar, D. Size-broadening anisotropy in whole powder pattern fitting. Application to zinc oxide and interpretation of the apparent crystallites in terms of physical models. J. Appl. Crystallogr. 2008, 41, 615-627. [CrossRef]

60. De Figueiredo, L.P.; Ferreira, F.F. The Rietveld Method as a Tool to Quantify the Amorphous Amount of Microcrystalline Cellulose. J. Pharm. Sci. 2014, 103, 1394-1399. [CrossRef] [PubMed]

61. Chen, L.; Wang, Q.; Hirth, K.; Baez, C.; Agarwal, U.P.; Zhu, J.Y. Tailoring the yield and characteristics of wood cellulose nanocrystals (CNC) using concentrated acid hydrolysis. Cellulose 2015, 22, 1753-1762. [CrossRef]

62. Lomelí-Ramírez, M.G.; Valdez-Fausto, E.M.; Rentería-Urquiza, M.; Jiménez-Amezcua, R.M.; Anzaldo Hernández, J.; TorresRendon, J.G.; García Enriquez, S. Study of green nanocomposites based on corn starch and cellulose nanofibrils from Agave tequilana Weber. Carbohydr. Polym. 2018, 201, 9-19. [CrossRef]

63. Naseri, N.; Mathew, A.P.; Girandon, L.; Fröhlich, M.; Oksman, K. Porous electrospun nanocomposite mats based on chitosancellulose nanocrystals for wound dressing: Effect of surface characteristics of nanocrystals. Cellulose 2015, 22, 521-534. [CrossRef]

64. Rosa, M.F.; Medeiros, E.S.; Malmonge, J.A.; Gregorski, K.S.; Wood, D.F.; Mattoso, L.H.C.; Glenn, G.; Orts, W.J.; Imam, S.H. Cellulose nanowhiskers from coconut husk fibers: Effect of preparation conditions on their thermal and morphological behavior. Carbohydr. Polym. 2010, 81, 83-92. [CrossRef]

65. Siqueira, G.; Tapin-Lingua, S.; Bras, J.; da Silva Perez, D.; Dufresne, A. Morphological investigation of nanoparticles obtained from combined mechanical shearing, and enzymatic and acid hydrolysis of sisal fibers. Cellulose 2010, 17, 1147-1158. [CrossRef]

66. Hanaor, D.; Michelazzi, M.; Leonelli, C.; Sorrell, C.C. The effects of carboxylic acids on the aqueous dispersion and electrophoretic deposition of ZrO2. J. Eur. Ceram. Soc. 2012, 32, 235-244. [CrossRef]

67. International Organization for Standardization (ISO). Particle Size Analysis-Dynamic Light Scattering (DLS); ISO 22412; ISO: Geneva, Switzerland, 2017. 
68. Ramírez Casillas, R.; Báez Rodríguez, K.F.; Cruz-Estrada, R.H.; Dávalos-Olivares, F.; Navarro-Arzate, F.; Satyanarayana, K.G. Isolation and Characterization of Cellulose Nanocrystals Created from Recycled Laser Printed Paper. BioResources 2018, 13, 7404-7429. [CrossRef]

69. Gonzalez-Ramirez, J.R. Obtención y modificación de Nanocristales de celulosa de bagazo de Agave tequilana Weber variedad azul y su uso en matrices poliméricas. Master's Thesis, Universidad de Guadalajara, Guadalajara, Mexico, 2020. Unpublished.

70. Gallardo-Sanchez, M.A. Obtención y caracterización de nanocristales de celulosa a partir de desechos agro-industriales de Agave tequilana Weber var. azul y su uso como refuerzo en matrices cementantes. Ph.D. Thesis, Universidad de Guadalajara, Guadalajara, Mexico, 2019; Unpublished. 